\title{
The Stock Market and Corporate Investment: A Test of Catering Theory
}

\author{
Christopher Polk \\ London School of Economics
}

\author{
Paola Sapienza \\ Northwestern University, CEPR, and NBER
}

\begin{abstract}
We test a catering theory describing how stock market mispricing might influence individual firms' investment decisions. We use discretionary accruals as our proxy for mispricing. We find a positive relation between abnormal investment and discretionary accruals; that abnormal investment is more sensitive to discretionary accruals for firms with higher R\&D intensity (opaque firms) or share turnover (firms with shorter shareholder horizons); that firms with high abnormal investment subsequently have low stock returns; and that the larger the relative price premium, the stronger the abnormal return predictability. We show that patterns in abnormal returns are stronger for firms with higher R\&D intensity or share turnover. (JEL G14, G31)
\end{abstract}

In this paper, we study whether mispricing in the stock market has consequences for firm investment policy. We test a "catering" channel, through which deviations from fundamentals may affect investment decisions directly. If the market misprices firms according to their level of investment, managers may try to boost short-run share prices by catering to current sentiment. Firms with ample cash or debt capacity may have an incentive to waste resources in negative NPV projects when their stock price is overpriced and to forgo positive investment opportunities when their stock price is undervalued. Managers with shorter shareholder horizons, and those whose assets are more difficult to value, should cater more.

\footnotetext{
This paper previously circulated with the title "The Real Effects of Investor Sentiment." We thank an anonymous referee, Andy Abel, Malcolm Baker, David Brown, David Chapman, Randy Cohen, Kent Daniel, Arvind Krishnamurthy, Terrance Odean, Owen Lamont, Patricia Ledesma, Vojislav Maksimovic, Bob McDonald, Mitchell Petersen, Fabio Schiantarelli, Andrei Shleifer, Jeremy Stein, Tuomo Vuolteenaho, Ivo Welch, Luigi Zingales, and seminar participants at Harvard Business School, Helsinki School of Economics, London Business School, McGill University, University of Chicago, University of Virginia, the AFA 2003 meeting, the NBER Behavioral Finance Program meeting, the Texas Finance Festival, the University of Illinois Bear Markets conference, the Yale School of Management, the WFA 2002 meeting, and the Zell Center Conference on "Risk Perceptions and Capital Markets." We thank Sandra Sizer for editorial assistance. We acknowledge support from the Investment Analysts Society of Chicago Michael J. Borrelli CFA Research Grant Award. Polk acknowledges the support of the Searle Fund. The usual caveat applies. Send correspondence to Paola Sapienza, Finance Department, Kellogg School of Management, Northwestern University, 2001 Sheridan Rd., Evanston IL 60208; telephone: 1-847-491-7436; fax: 1-847-491-5719; E-mail: Paola-Sapienza@northwestern.edu.
}

(C) The Author 2008. Published by Oxford University Press on behalf of the Society for Financial Studies. All rights reserved. For permissions, please e-mail: journals.permissions@oxfordjournals.org. 
We rely on discretionary accruals, a measure of the extent to which the firm has abnormal noncash earnings, to identify mispricing. Firms with high discretionary accruals have relatively low stock returns in the future, suggesting that they are overpriced. We regress firm-level investment on discretionary accruals while controlling for investment opportunities, as measured by Tobin's $Q$.

We find a positive relation between discretionary accruals and firm investment. Our result is robust to several alternative specifications, as well as to corrections for measurement error in Tobin's $Q$, our proxy for investment opportunities.

Exploiting the intuition of Stein's (1996) short-horizons model, we show that a misallocation of investment capital is more likely to occur when the expected duration of mispricing is relatively long and shareholders have relatively short investment horizons. In other words, managers with shorter shareholder horizons, and those whose assets are more difficult to value, should cater more. To test these cross-sectional predictions, we analyze the relation between discretionary accruals and investment for firms that are more opaque (higher R\&D intensity) and for firms that have short-term investors (higher firms' share turnover). We find that firms with higher R\&D intensity and share turnover have investment that is more sensitive to discretionary accruals.

Our results provide evidence that discretionary accruals and firm investment are positively correlated. However, they show only indirectly that firms that overinvest are overpriced. To address this point, we analyze the relation between investment and future stock returns. If firms are misallocating resources due to market misvaluation, then abnormal investment should predict risk-adjusted returns. We estimate cross-sectional regressions of future monthly stock returns on current investment, controlling for investment opportunities (Tobin's $Q$ ) and financial slack. We find that firms with high (low) abnormal investment have low (high) stock returns on average. This finding is robust to controlling for other characteristics linked to return predictability. Consistent with the theory's prediction, we find that this effect is stronger for firms with higher R\&D intensity or higher share turnover.

Finally, we show that this catering incentive varies over time. Following Baker and Wurgler (2004), we measure the extent to which high-abnormal investment firms command a price premium relative to low-abnormal investment firms. We find that when this abnormal-investment premium is relatively high, overinvesting firms have a particularly high increase in subsequent abnormal investment and particularly low subsequent abnormal returns.

Our paper is related to the studies that analyze how stock mispricing affects investment via equity issuance (Baker and Wurgler, 2002). Stein (1996) shows that if the company's stock is mispriced, a manager can issue overvalued stock or buy back undervalued equity. When stock prices are above fundamentals, rational managers of equity-dependent firms find it more attractive to issue equity. By contrast, when stock prices are below fundamental values, managers 
of equity-dependent firms do not invest, because for them, investment requires the issuance of stock at too low of a price. Baker, Stein, and Wurgler (2003) test this hypothesis directly and find evidence that stock market mispricing does influence firms' investment through an equity issuance channel (see also Jensen, 2005).

In this paper, we ask a complementary question: Is there an alternative channel that directly affects firm investment decisions, one that is not linked to equity issuance decisions? We believe that this alternative mechanism is important, since retained earnings rather than equity issuance are by far the bigger source of funds for capital investment. ${ }^{1}$ Because seasoned equity offerings are rarely used to finance investment, we also believe it is important to assess whether firms change their investment policies according to the valuation of their stock, even if they are not issuing equity to finance these investments.

Furthermore, this alternative mechanism has very different implications for the type of investment chosen. Managers with long horizons make efficient investment decisions by assumption. Alternatively, if stock market valuation affects investment decision through a catering channel, managers may make an investment that has a negative NPV (and avoid investment that has a positive NPV) as long as this strategy increases the stock price in the short run.

In all our main tests, we distinguish between the catering channel and the equity issuance channel by controlling for equity issuance, or dropping from our sample all firms with positive equity issuance over the year. We find that our results are robust to these modifications, thus supporting the hypothesis that deviations from fundamentals can affect investment decisions through a catering channel, which is independent from the evidence of Baker, Stein, and Wurgler (2003).

Our paper is also related to previous studies that investigated whether inefficient capital markets may actually affect corporate investment policies. These studies investigated whether stock market variables have predictive power for investment (Barro, 1990; Morck, Shleifer, and Vishny, 1990; and Blanchard, Rhee, and Summers, 1993). More recently, Chirinko and Schaller (2001) claim that the bubble in Japanese equity markets during the period 1987-1989 boosted business-fixed investment by approximately 6-9\%. Panageas (2005) and Gilchrist, Himmelberg, and Huberman (2005) find evidence that investment is sensitive to proxies for mispricing. ${ }^{2}$

The difference between our approach and these other papers is that we analyze whether mispricing affects investment through the catering channel. Therefore, as mentioned before, in all our regressions we control for equity issuance to isolate the catering channel from other channels.

\footnotetext{
1 See Mayer (1988); and Rajan and Zingales (1995), for example. Froot, Scharfstein, and Stein (1994) claim that "Indeed, on average, less than two percent of all corporate financing comes from the external equity market." More recently, Mayer and Sussman (2003) analyze the source of financing of large investments for US companies. They find that most large investments are financed by new debt and retained earnings.

2 See Baker, Ruback, and Wurgler (forthcoming) for an excellent survey.
} 
The paper is organized as follows. In Section 1, we motivate our empirical work by detailing a simple model of firm investment. We describe the data and report the results in Section 2. Section 3 concludes.

\section{Investment Decisions and Mispricing}

Following Stein (1996), in this model we show how stock price deviations from fundamental value may have a direct effect on the investment policy of a firm. We consider a firm that uses capital, $K$ at time 0 to produce output. $K$ is continuous and homogenous with price $c$. The true value of the firm at time $t$ is $V(K)$. The market value of firm at time $t$ is $V^{m k t}(K)=\left(1+\alpha_{t}\right) V(K)$, where $\alpha_{t}$ measures the extent to which the firm is mispriced. Firm misvaluation depends on this level of mispricing $\alpha$, which disappears over time at the rate $p$. Specifically, at $\alpha_{t}=\alpha e^{-p t}$.

We assume that shareholders may have short horizons. Each shareholder $j$ will need liquidity at some point in time, $t+u$, where the arrival of this liquidity need follows a Poisson process with mean arrival rate $q_{j} \in[0, \infty)$. A small $q_{j}$ suggests that the particular shareholder is a long-term shareholder who intends to sell the stock many years after the initial investment. A short-term investor has a large $q_{j}$.

We define shareholder $j$ 's expected utility at time 0 as

$$
Y_{j}^{t} \equiv \int_{u=0}^{\infty}\left(1+\alpha e^{-p t}\right) q_{j} e^{-q_{j} t} V(K) d t-\left(K-K_{0}\right) c .
$$

The shareholder's expected level of income is a weighted average of the share price before and after the true value of the company is revealed. For simplicity, in Equation (1) we normalize the number of shares to one. The equation shows that the expected level of the shareholder's income depends on how likely the shareholder is to receive a liquidity shock before the stock price reflects the true value of the company. We denote $q$ as the arrival rate of the average shareholder. The larger $q$ is (the more impatient investors are, on average), the higher the weight on the informationally inefficient share price. The larger $p$ is (a firm with shorter maturity projects), the higher the weight on the share price under symmetric information. The FOC of the manager's problem $^{3}$ is as follows:

$$
V^{\prime}(K)=\frac{c}{\gamma}
$$

where $\gamma \equiv 1+\frac{\alpha q}{q+p}$.

\footnotetext{
${ }^{3}$ We assume that the manager is rational, maximizes shareholders' wealth, but that shareholders have short horizons. This assumption is equivalent to the assumption in Stein (1996) that managers are myopic. Also, Stein (1988); and Shleifer and Vishny (1990) model myopia.
} 
The optimal investment level is $K^{*}$ when there is no mispricing $(\alpha=0)$, which satisfies $V^{\prime}\left(K^{*}\right)=c$. When the firm is overpriced ( $\alpha$ is positive), the manager invests more than $K^{*}$. Even if the marginal value from the investment is lower than the cost of investing, the market's tendency to overvalue the investment project may more than compensate for the loss from the valuedestroying investment. In other words, the temporary overvaluation of the project more than compensates for the "punishment" the market imposes on the firm at the time when the firm becomes correctly priced.

The incentive to overinvest increases as the expected duration of mispricing increases ( $p$ becomes smaller) and decreases as the horizon of the average shareholder lengthens ( $q$ becomes larger). Intuitively, if managers expect the current overvaluation to last, and if investors have short horizons, then managers increase investment to take advantage of the mispricing.

Similarly, underinvestment occurs when firms are underpriced. If the market is pessimistic about the value of the firm ( $\alpha$ is negative), the manager will invest too little. The level of investment will be lower as the expected duration of mispricing increases and/or the horizon of the average shareholder shortens. ${ }^{4}$

\section{Empirical Analysis}

\subsection{Data}

Most of our data come from the merged CRSP-Compustat database, which is available to us through Wharton Research Data Services. Our sample comprises firms over the period 1963-2000. We do not include firms with negative accounting numbers for book assets, capital, or investment. When explaining investment, we study only firms with a December fiscal year-end. Doing so eliminates the usual problems caused by the use of overlapping observations. We drop firms with sales less than $\$ 10$ million, and extreme observations (see Appendix for details).

We intersect the initial sample with the Zacks database, which provides analyst consensus estimates of earnings one, two, and five years out. Table 1 reports summary statistics for our sample of firms.

\subsection{Discretionary accruals and investment}

In all our analyses, we estimate linear models of firm investment. A very large previous literature has studied the properties of that central firm decision. ${ }^{5}$ Our specification regresses firm investment on discretionary accruals (our proxy for mispricing), a proxy for Tobin's $Q$, and firm cash flow, controlling for

\footnotetext{
${ }^{4}$ Our modeling of the expected duration of mispricing is quite stylized. A more in-depth analysis of the interaction between asymmetric information and mispricing, as modeled in a previous version of the paper, is available on request.

5 See Stein (2003) for a recent summary of that literature.
} 
Table 1

Summary statistics

\begin{tabular}{lcccccc} 
& Mean & Median & Std. dev. & Min & Max & Obs. \\
\hline$I_{i, t} / K_{i, t-1}$ & 0.2625 & 0.1959 & 0.2991 & 0.0001 & 9.2656 & 31,659 \\
$D_{C C C R_{i, t}}$ & -0.0066 & -0.0035 & 0.0998 & -1.3740 & 1.7906 & 31,659 \\
$Q_{i, t-1}$ & 1.3985 & 1.0926 & 1.1370 & 0.1367 & 51.4978 & 31,659 \\
$C F_{i, t-1} / K_{i, t-2}$ & 0.3786 & 0.2773 & 0.8305 & -9.9668 & 9.9804 & 31,659 \\
$S_{i, t-1}$ & 1516 & 251 & 5206 & 10 & 206083 & 31,659 \\
$A_{i, t-1}$ & 1775 & 221 & 7041 & 2 & 407200 & 31,659 \\
$E Q I S S_{i, t}$ & 16.92 & 0.21 & 93.13 & -145.00 & 4463.40 & 30,490 \\
\hline$K_{i, t-1}\left[E A R N_{i, t}\right] / A_{i, t-1}$ & 0.0480 & 0.0459 & 0.1379 & -6.159 & 13.148 & 16,493 \\
$E_{t-1}\left[E A R N_{i, t+1}\right] / A_{i, t-1}$ & 0.0686 & 0.0574 & 0.0794 & -3.850 & 2.063 & 15,875 \\
$E_{t-1}\left[E A R N_{i, t+4}\right] / A_{i, t-1}$ & 1.0052 & 0.4186 & 2.8974 & -2.404 & 120.73 & 13,718 \\
$R \& D_{i, t-1} / A_{i, t-1}$ & 0.0401 & 0.0215 & 0.0593 & 0 & 2.052 & 15,360 \\
$T U R N_{i, t-1}$ & 1.653 & 1.158 & 1.736 & 0 & 22.218 & 17,183 \\
$B E / M E_{i, t-1}$ & 0.949 & 0.949 & 0.988 & 0 & 47.290 & 109,963 \\
$M E_{i, t-1}$ & 694,555 & 55,176 & $4,664,206$ & 101 & $417,578,432$ & 109,963 \\
$M O M_{i, t-1}$ & 1.1433 & 1.0453 & 0.6583 & 0.0042 & 30.1818 & 109,963 \\
$K Z$ & -2.2864 & -0.5199 & 81.1512 & -544.505 & 13886 & 30,175 \\
\hline
\end{tabular}

We obtain our data from the merged CRSP-Compustat and the Zacks database. Investment, $I_{i, t-1}$, is capital expenditure (Compustat Item 128). Capital, $K_{i, t-1}$, is net property, plant, and equipment (Compustat Item 8). We define discretionary accruals, $D A C C R_{i, t}$, as the difference between realized accruals and normal accruals as forecast by Chan et al's. (2001) model. In this model, normal accruals are computed as a constant proportion of firm sales estimated using the last five years. See the Appendix for details. Tobin's $Q, Q_{i, t-1}$, is defined as the market value of assets divided by the book value of assets, $A_{i, t-1}$ (Compustat Item 6). A firm's market value of assets equals the book value of assets plus the market value of common stock less the sum of book value of common stock (Compustat Item 60) and balance sheet deferred taxes (Compustat Item 74). Cash flow, $C F_{i, t-1} / K_{i, t-2}$, equals the sum of earnings before extraordinary items (Compustat Item 18) and depreciation (Compustat Item 14) over beginning-of-year capital which we define as net property, plant, and equipment (Compustat Item 8). The one-year expected profitability, $E_{t-1}\left[E A R N_{i, t}\right] / A_{i, t-1}$, is the median analyst year $t-1$ forecast of earnings in year $t$ divided by the book value of assets in year $t-1$. The two-year expected profitability, $E_{t-1}\left[E A R N_{i, t+1}\right] / A_{i, t-1}$, is the median analyst year $t-1$ forecast of earnings in years $t$ and $t+1$ divided by the book value of assets in year $t-1$. The five-year expected profitability, $E_{t-1}\left[E A R N_{i, t+4}\right] / A_{i, t-1}$, is the median analyst year $t-1$ forecast of earnings in years $t$ through $t+4$ divided by the book value of assets in year $t-1$. $R \& D_{i, t-1} / A_{i, t-1}$ measures $\mathrm{R} \& \mathrm{D}$ intensity ( $\mathrm{R} \& \mathrm{D}$ expense (Compustat Item 46) over the book value of assets). Share turnover, $T U R N_{i, t-1}$ is the average, in December ${ }_{t-1}$, of the daily ratio of shares traded to shares outstanding at the end of the day. $B E / M E_{i, t}$ is firm book-to-market equity. $M E_{i, t}$ is firm book-to-market equity. $M O M_{i, t}$ is firm stock-return momentum. We describe these last three variables in the Appendix. $K Z_{i, t}$ is Kaplan-Zingales (1997) index of financial constraints, also defined in the Appendix.

firm- $\left(f_{i}\right)$ and year- $\left(\gamma_{t}\right)$ fixed effects,

$$
\frac{I_{i, t}}{K_{i, t-1}}=f_{i}+\gamma_{t}+b_{1} \alpha_{i, t}+b_{2} Q_{i, t-1}+b_{3} \frac{C F_{i, t-1}}{K_{i, t-2}}+\varepsilon_{i, t} .
$$

The dependent variable is individual firms' investment-capital ratios $\left(\frac{I_{i, t}}{K_{i, t-1}}\right)$, where investment, $I_{i, t}$, is capital expenditure and capital, $K_{i, t-1}$, is beginningof-year net property, plant, and equipment. Tobin's $Q, Q_{i, t-1}$, is beginningof-period market-to-book.

The market value of assets equals the book value of assets plus the market value of common stock less the sum of book value of common stock and balance sheet deferred taxes. $C F_{i, t-1} / K_{i, t-2}$ equals the sum of earnings before extraordinary items and depreciation over beginning-of-year capital.

Our analysis critically depends on identifying situations where firms are mispriced $(\alpha)$. As Fama (1970) points out, testing market efficiency also requires 
a model of market equilibrium. Thus, any evidence linking investment to mispricing can never be conclusive as that mispricing can also be interpreted as compensation for exposure to risk. Therefore, although we use discretionary accruals, a variable that is difficult to link to risk, we note that our evidence could be interpreted as rational under some unspecified model of market equilibrium.

Our proxy for mispricing exploits firms' use of accrual accounting. Accruals represent the difference between a firm's accounting earnings and its underlying cash flow. For example, large positive accruals indicate that earnings are much higher than the cash flow generated by the firm.

Several papers show a strong correlation between discretionary accruals and subsequent stock returns, suggesting that firms with high discretionary accruals are overpriced relative to otherwise similar firms. For example, Sloan (1996) finds that those firms with relatively high (low) levels of abnormal accruals experience negative (positive) future abnormal stock returns concentrated around future earning announcements. Teoh, Welch, and Wong (1998a,b) find that IPO and SEO firms who have the highest discretionary accruals have the lowest abnormal returns post equity issue. More recently, Chan et al. (2001) investigate the relation between discretionary accruals and stock returns. Confirming previous results, they also find that firms with high (low) discretionary accruals do poorly (well) over the subsequent year. Most of the abnormal performance is concentrated in the firms with very high discretionary accruals. ${ }^{6}$

We use past evidence on the correlation between discretionary accruals and stock returns to justify the use of discretionary accruals as our mispricing proxy. We measure accruals $\left(A C C R_{i, t}\right)$ by

$$
\operatorname{ACCR}_{(i, t)}=\triangle N C C A-\triangle C L-D E P,
$$

where $\triangle N C C A$ is the change in noncash current assets, $\triangle C L$ is the change in current liabilities minus the change in debt included in current liabilities and minus the change in income taxes payable, and DEP is depreciation and amortization.

The differences between earnings and cash flow arise because of accounting conventions as to when, and to what extent, firms recognize revenues and costs. Within those conventions, managers have discretion over accruals adjustments and may use them to manage earnings. For example, a manager can modify accruals by delaying recognition of expenses after advancing cash to suppliers, by advancing recognition of revenues with credit sales, by decelerating depreciation, or by assuming a low provision for bad debt.

To capture the discretionary component of discretionary accruals, we follow Chan et al. (2001) such that

$$
D_{A C C R_{i, t}}=A C C R_{i, t}-N O R M A L A C C R_{i, t},
$$

\footnotetext{
6 These results are puzzling because, in principle, if investors can detect earnings manipulation, higher accruals should not affect the stock price. However, a large body of evidence indicates that investors seem to simply focus on earnings (see Hand, 1990; and Maines and Hand, 1996).
} 


$$
\operatorname{NORMALACCR}_{i, t}=\frac{\sum_{k=1}^{5} A_{C C R_{i, t-k}}}{\sum_{k=1}^{5} S A L E S_{i, t-k}} \operatorname{SAES}_{i, t},
$$

where we scale accruals by total assets and model $N O R M A L A C C R_{i, t}$ as a constant proportion of firm sales. In other words, to capture the discretionary component of accruals, we assume that the necessary accruals adjustments are firm-specific. ${ }^{7}$ For example, asset-intensive firms typically have relatively high depreciation.

In Table 2, Panel A, column (1) displays the results of regression (3). When we control for investment opportunities and cash flow, we find that firms with high discretionary accruals invest more. The coefficient of investment on discretionary accruals measures 0.201 with an associated $t$-statistic of 8.78 . Firms with abnormally soft earnings invest more than the standard model would indicate. This effect is economically important. A one-standard-deviation change in a typical firm's level of discretionary accruals is associated with roughly a $2 \%$ change in that firm's investment as a percentage of capital, which corresponds to $7 \%$ of the sample mean. Our results are consistent with a recent paper by Bergstresser, Desai, and Rauh (2004) that shows that a specific type of earnings manipulation based on the assumed rate of return on pension assets for companies with defined benefit pension plans is correlated with investment decisions.

Note that Abel and Blanchard (1986) suggest that mispricing may smear the information in $Q$ concerning investment opportunities. This possibility actually works against us finding any independent effect of discretionary accruals. If $Q$ is correlated with mispricing, then the coefficient of discretionary accruals underestimates the effect of mispricing on investment.

One way to interpret our results is that overpriced equity allows firms to issue equity and finance investment. Baker, Stein, and Wurgler (2003) show that mispricing affects investment decisions through an equity channel. Firms that are overpriced issue more equity (Baker and Wurgler, 2000, 2002). If the firm is cash constrained and is not investing optimally before issuing equity, then more equity issuance translates into more investment.

As noted above, we want to test whether there is an additional channel that links equity mispricing to investment. We want to find out if managers cater

\footnotetext{
7 We have also estimated (Polk and Sapienza, 2004) the discretionary component of accruals using the crosssectional adaptation developed in Teoh, Welch, and Wong (1998a,b) of the modified Jones' (1991) model. Specifically, we estimated expected current accruals for each firm in a given year from a cross-sectional regression in that year of current accruals on the change in sales using an estimation sample of all two-digit SIC code peers. All our results are substantially the same when we use this alternative measure. Hribar and Collins (2002) argue that the Jones' method is potentially flawed as it calculates accruals indirectly using balance sheet information rather than directly using income statement information. In particular, they point out that the presumed equivalence between the former and the latter breaks down when nonoperating events, such as reclassifications, acquisitions, divestitures, accounting changes, and foreign currency translations occur. Hribar and Collins show that these "non-articulating" events generate nontrivial measurement error in calculations of discretionary accruals. However, our results still hold even when we restrict the analysis to a subsample of firms that do not have such nonarticulation events or when we use income statement accruals in a post-1987 sample, where the necessary income-statement accruals information is available.
} 
Table 2

Discretionary accruals and firm investment

Panel A

\begin{tabular}{|c|c|c|c|c|c|c|c|c|}
\hline & (1) & (2) & (3) & (4) & (5) & (6) & (7) & (8) \\
\hline$D A C C R_{i, t}$ & $\begin{array}{l}0.2010^{* * *} \\
(0.0229)\end{array}$ & $\begin{array}{l}0.1987^{* * *} \\
(0.0236)\end{array}$ & $\begin{array}{l}0.2352^{* * *} \\
(0.0320)\end{array}$ & $\begin{array}{l}0.2456^{* * *} \\
(0.0320)\end{array}$ & $\begin{array}{l}0.2755^{* * *} \\
(0.0395)\end{array}$ & $\begin{array}{c}0.1842^{* * * *} \\
(0.0240)\end{array}$ & $\begin{array}{c}0.1783^{* * *} \\
(0.0238)\end{array}$ & $\begin{array}{c}0.1736^{* * *} \\
(0.0240)\end{array}$ \\
\hline$Q_{i, t-1}$ & $\begin{array}{l}0.0544^{* * *} \\
(0.0055)\end{array}$ & $\begin{array}{l}0.0529^{* * *} \\
(0.0056)\end{array}$ & $\begin{array}{l}0.0524^{* * *} \\
(0.0062)\end{array}$ & $\begin{array}{l}0.0533^{* * *} \\
(0.0084)\end{array}$ & $\begin{array}{l}0.0538^{* * *} \\
(0.0113)\end{array}$ & $\begin{array}{c}0.0532^{* * * *} \\
(0.0077)\end{array}$ & $\begin{array}{c}0.0556^{* * *} \\
(0.0075)\end{array}$ & $\begin{array}{c}0.0549^{* * *} \\
(0.0075)\end{array}$ \\
\hline$C F_{i, t-1} / K_{i, t-2}$ & $\begin{array}{l}0.0743^{* * *} \\
(0.0084)\end{array}$ & $\begin{array}{l}0.0711^{* * *} \\
(0.0082)\end{array}$ & $\begin{array}{l}0.0495^{* * *} \\
(0.0076)\end{array}$ & $\begin{array}{l}0.0492^{* * *} \\
(0.0086)\end{array}$ & $\begin{array}{l}0.0545^{* * *} \\
(0.0143)\end{array}$ & $\begin{array}{c}0.0738^{* * *} \\
(0.0092)\end{array}$ & $\begin{array}{c}0.0709^{* * *} \\
(0.0087)\end{array}$ & $\begin{array}{r}0.0697^{* * *} \\
(0.0088)\end{array}$ \\
\hline$\frac{E Q I S S_{i, t}}{K_{i, t-1}}$ & & $0.0129^{* *}$ & $0.0114^{* *}$ & $0.0131^{* *}$ & 0.0114 & $0.0129^{* *}$ & $0.0099^{* *}$ & $0.0105^{*}$ \\
\hline$E_{t-1}\left[\operatorname{EARN}_{i, t}\right] / A_{i, t-1}$ & & $(0.0056)$ & $\begin{array}{r}(0.0049) \\
0.0399^{*} \\
(0.0217)\end{array}$ & $\begin{array}{r}(0.0058) \\
0.4345^{*} \\
(0.2631)\end{array}$ & $\begin{array}{c}(0.0075) \\
0.9574^{* *} \\
(0.3893)\end{array}$ & (0.0059) & $(0.0050)$ & $(0.0056)$ \\
\hline$E_{t-1}\left[E A R N_{i, t+1}\right] / A_{i, t-1}$ & & & & $\begin{array}{c}-0.5093 \\
(0.4458)\end{array}$ & $\begin{array}{l}-1.2025 \\
(0.7815)\end{array}$ & & & \\
\hline$E_{t-1}\left[E A R N_{i, t+4}\right] / A_{i, t-1}$ & & & & & $\begin{array}{l}0.0119^{*} \\
(0.0068)\end{array}$ & & & \\
\hline$Q_{i, t}$ & & & & & & $\begin{array}{c}0.0036 \\
(0.0059)\end{array}$ & $\begin{array}{c}0.0025 \\
(0.0060)\end{array}$ & $\begin{array}{c}0.0026 \\
(0.0061)\end{array}$ \\
\hline$Q_{i, t-2}$ & & & & & & & $\begin{array}{c}-0.0089^{* *} \\
(0.0040)\end{array}$ & $\begin{array}{c}-0.0079^{*} \\
(0.0044)\end{array}$ \\
\hline$Q_{i, t-3}$ & & & & & & & & $\begin{array}{l}-0.0024 \\
(0.0043)\end{array}$ \\
\hline Observations & 31659 & 30490 & 15976 & 15374 & 13053 & 29153 & 28532 & 28053 \\
\hline$R$-squared & 0.430 & 0.434 & 0.542 & 0.554 & 0.536 & 0.440 & 0.448 & 0.449 \\
\hline
\end{tabular}


Table 2

Continued

Panel B

\begin{tabular}{|c|c|c|c|c|c|c|c|}
\hline & (1) & (2) & (3) & (4) & (5) & (6) & (7) \\
\hline$D A C C R_{i, t}$ & $\begin{array}{c}0.1471^{* * * *} \\
(0.0340)\end{array}$ & $\begin{array}{l}0.1798^{* *} \\
(0.0715)\end{array}$ & $\begin{array}{l}0.1359^{* *} \\
(0.0538)\end{array}$ & $\begin{array}{c}0.0982 \\
(0.0651)\end{array}$ & $\begin{array}{c}0.1387^{\text {**** }} \\
(0.0337)\end{array}$ & $\begin{array}{c}0.1406^{* * *} \\
(0.0342)\end{array}$ & $\begin{array}{c}0.1390^{* * *} \\
(0.0349)\end{array}$ \\
\hline$Q_{i, t-1}$ & $\begin{array}{c}0.0441^{* * * *} \\
(0.0108)\end{array}$ & $\begin{array}{c}0.0373^{* * *} \\
(0.0116)\end{array}$ & $\begin{array}{c}0.0382^{* * * *} \\
(0.0123)\end{array}$ & $\begin{array}{c}0.0159 \\
(0.0111)\end{array}$ & $\begin{array}{c}0.0387^{* * * *} \\
(0.0126)\end{array}$ & $\begin{array}{c}0.0410^{* * * *} \\
(0.0121)\end{array}$ & $\begin{array}{c}0.0421^{* * *} \\
(0.0115)\end{array}$ \\
\hline$C F_{i, t-1} / K_{i, t-2}$ & $\begin{array}{c}0.0744^{* * *} \\
(0.0140)\end{array}$ & $\begin{array}{l}0.0796^{* *} \\
(0.0327)\end{array}$ & $\begin{array}{l}0.0836^{* *} \\
(0.0360)\end{array}$ & $\begin{array}{l}0.1073^{*} \\
(0.0626)\end{array}$ & $\begin{array}{c}0.0702^{* * * *} \\
(0.0141)\end{array}$ & $\begin{array}{c}0.0712^{* * * *} \\
(0.0145)\end{array}$ & $\begin{array}{c}0.0649^{* * *} \\
(0.0135)\end{array}$ \\
\hline$E_{t-1}\left[E A R N_{i, t}\right] / A_{i, t-1}$ & & $\begin{array}{l}0.0655^{* *} \\
(0.0301)\end{array}$ & $\begin{array}{l}-0.0475 \\
(0.1359)\end{array}$ & $\begin{array}{c}0.1529 \\
(0.3496)\end{array}$ & & & \\
\hline$E_{t-1}\left[E A R N_{i, t+1}\right] / A_{i, t-1}$ & & & $\begin{array}{c}0.1404 \\
(0.2018)\end{array}$ & $\begin{array}{c}0.4248 \\
(0.2819)\end{array}$ & & & \\
\hline$E_{t-1}\left[E A R N_{i, t+4}\right] / A_{i, t-1}$ & & & & $\begin{array}{c}0.0130 \\
(0.0117)\end{array}$ & & & \\
\hline$Q_{i, t}$ & & & & & $\begin{array}{c}0.0068 \\
(0.0093)\end{array}$ & $\begin{array}{c}0.0073 \\
(0.0098)\end{array}$ & $\begin{array}{c}0.0062 \\
(0.0096)\end{array}$ \\
\hline$Q_{i, t-2}$ & & & & & & $\begin{array}{l}-0.0131^{* *} \\
(0.0065)\end{array}$ & $\begin{array}{l}-0.0077 \\
(0.0065)\end{array}$ \\
\hline$Q_{i, t-3}$ & & & & & & & $\begin{array}{l}-0.0066 \\
(0.0079)\end{array}$ \\
\hline Observations & 10433 & 0 & 3528 & 2825 & 10132 & 9854 & 9600 \\
\hline$R$-squared & 0.426 & 0.569 & 0.605 & 0.630 & 0.433 & 0.447 & 0.466 \\
\hline
\end{tabular}

The dependent variable is the proportion of investment over beginning-of-year capital. For a description of all the other variables, see the legend of Table 1. Panel A shows the results for the entire sample. All columns report coefficients and standard errors from OLS regressions. In Panel B, we repeat the same specification, but now we exclude companies that have positive equity issuance (Compustat Item 108). All regressions include firm- and year-fixed effects. The standard errors reported in parentheses are corrected for clustering of the residual at the firm level. Coefficients starred with one, two, and three asterisks are statistically significant at the $10 \%, 5 \%$, and $1 \%$ levels, respectively. 
to investor demand by investing more when investors overprice the stock. The investment catering channel works independently from the decision to issue equity, because managers can temporarily boost the stock price by investing more.

To test whether our results are consistent with the catering channel, in Table 2, Panel A, column (2), and all in subsequent similar regressions, we control for cash from the sale of common and preferred stocks (Compustat Item 108) scaled by $K_{i, t-1}$ (beginning-of-year net property, plant, and equipment), $\frac{E Q I S S_{i, t}}{K_{i, t-1}}$.

We find that a one-standard-deviation change in equity issuance positively affects investment by a $1.2 \%$ change in that firm's investment as a percentage of capital. This finding is consistent with Baker, Stein, and Wurgler (2003). More important for our hypothesis, the discretionary accruals coefficient remains essentially the same as before, confirming that the catering channel has an independent effect: One-standard-deviation change in the firm's level of discretionary accruals is associated with a $2 \%$ change in firm investment over capital, which corresponds to $7 \%$ of the sample mean.

There are several potential problems in our baseline regression that might undermine the interpretation of the results. The most obvious problem arises from the fact that the disappointing performance of our measure of $Q$, even if it is consistent with the results in other studies, suggests that this measure may be a poor proxy for true marginal $Q .{ }^{8}$

If our mispricing variable is a good indicator of unobserved investment opportunities, then the existence of measurement error in Tobin's $Q$ is a particularly serious problem in our analysis. For example, we could argue that firms with high discretionary accruals may have very profitable growth options that their average $Q$ only partially reflects. These firms should invest more. Fortunately, the evidence in other studies suggests exactly the opposite: firms with soft earnings are firms with poor growth opportunities. Teoh, Welch, and Wong (1998b) document that firms with high discretionary accruals tend to be seasoned equity issuers with relatively low postissue net income. Chan et al. (2001) show that, in general, firms with high discretionary accruals subsequently have a marked deterioration in their cash flows. Based on these findings, our measure of firm's mispricing is particularly appropriate in this context: it is hard to argue that the average $Q$ for this type of firm systematically understates marginal $Q$.

\footnotetext{
${ }^{8}$ Several papers have addressed this issue and found different results. For example, Abel and Blanchard (1986) construct aggregate marginal $Q$ and find little support for the view that the low explanatory power of average $Q$ is because it is a poor proxy for marginal $Q$. Similarly, Gilchrist and Himmelberg (1995) exploit Abel and Blanchard's technique at the level of the individual firm. Though their marginal $Q$ series seems to perform better than Tobin's $Q$, their qualitative results are not very different from the previous literature. Of course, their results critically depend on the quality of the alternative measure used. In a recent paper, Erickson and Whited (2000) point out that the various measures generally used in the literature all have an errors-in-variables problems and suggest an alternative solution. Erickson and Whited use a measurement-error-consistent generalized method of moments estimator that relies on information in higher moments of $Q$. With this estimator, they find that the accepted results in the previous literature (low explanatory power of Tobin's $Q$ and high explanatory power of cash flow) disappear.
} 
Even though current empirical studies suggest that abnormal noncash earnings are not positively correlated with investment opportunities, we still use several strategies from these studies on investment and $Q$ to address measurement error problems in our proxy for investment opportunities. First, we include analysts' consensus estimates of future earnings in our baseline regression. If analysts' forecasts are a good proxy for expected future profitability, this variable may be a good proxy for marginal $Q$. If we control for average $Q$, then higher marginal $Q$ should be positively correlated with higher expected future profitability.

In columns (2) through (4) of Table 2, Panel A, we add the ratio of consensus analyst forecast of cumulative firm profitability over assets one, two, and five years out to our baseline specification. The one-year earnings forecast has a positive effect on firms' investment decisions. The effect is small, but statistically significant at the 5\% level. A one-standard-deviation change in the one-year earning forecast is associated with roughly a $0.5 \%$ change in that firm's investment-to-capital ratio. This result suggests that this nonfinancial measure of future profitability has some information, even when we control for Tobin's $Q$. However, the coefficient on discretionary accruals actually increases from 0.1987 to 0.2352 .

In column (4) of Table 2, Panel A, we add both one- and two-year profitability estimates to our baseline regression. Discretionary accruals continue to be significant. In column (5), we include one-, two-, and five-year profitability forecasts. Discretionary accruals remain economically and statistically significant. $^{9}$

We also follow Abel and Eberly (2002) by using the long-term consensus earnings forecast as an instrument for $Q$. This instrument could be problematic because first, it is likely to be correlated with the measurement error in Tobin's $Q$; and second, as Bond and Cummins (2000) suggest, analyst forecasts may have an independent effect on investment. Nonetheless, when we estimate that regression, we find that when we use instrumental variables estimation, the significance of the discretionary accruals coefficient (not reported) is similar to our previous results.

To deal with the measurement error problem, we implement the Erickson and Whited $(2000,2002)$ method that exploits the information contained in higher moments to generate measurement-error-consistent GMM estimators of the relation between the investment and $Q$, and, consistent with their results and with the claim that there is measurement error in $Q$, we find that using this estimator increases the coefficient on $Q$ by an order of magnitude. ${ }^{10}$ Though our sample is reduced to satisfy the identifying assumption of Erickson and

9 Although we might be initially surprised by the negative coefficient on $E_{t-1}\left[E A R N_{i, t+1}\right] / A_{i, t-1}$, since earnings estimates are for cumulative earnings from $t-1$ to $t$, the negative coefficient indicates that the consensus one-year earnings two years from now have a relatively smaller impact on investment than consensus one-year earnings one year from now. In this light, the result seems reasonable.

${ }^{10}$ We thank Toni Whited for providing the Gauss code implementing their estimator. 
Whited (2000), the coefficient on discretionary accruals remains economically and statistically significant. (These results are available on request.)

Another potential problem with our baseline regression could arise because we measure average $Q$ at the beginning of the year in which we measure the firm's investment, but perhaps the firm's investment opportunities change over the year. As a result, our discretionary accruals measure might pick up this change in investment opportunities. Therefore, in Table 2, Panel A, column (6), we add to the baseline specification, end-of-period $Q_{i, t}$. Controlling for the change in $Q$ over the investment period has no effect on our results. Investment opportunities measured by end-of-period Tobin's $Q$ are not statistically significant and the estimated coefficient is $1 / 20$ of that on $Q_{i, t-1}$ in the baseline regression. Moreover, the estimated coefficient on discretionary accruals and the statistical significance of that estimate do not change.

We wish to ensure that our controls for investment opportunities are adequate if there is a lag between the time when a firm has investment opportunities and when we measure the actual investment. Therefore, the next two specifications include lags of $Q$ in response. In Table 2, Panel A, column (7), we add $Q_{t-2}$ to the specification in column (6). Although lagged investment opportunities explain firm investment, discretionary accruals still have a positive and significant effect on firm investment. Column (8) adds $Q_{t-3}$ to our specification. This variable is not significant and our results do not change. We conclude that the timing of our Tobin's $Q$ variable is not an issue.

We also examine the possibility that if discretionary accruals are correlated with a firm's amount of financial slack, then our variable might be picking up on the fact that financially constrained firms have less financial slack with which to invest. Firms with high discretionary accruals are those firms whose earnings are not backed by cash flow: firms with high discretionary accruals generally have little financial slack. However, we augment our baseline regression with both contemporaneous and two- and three-year lags of our cash flow variable, $C F_{i, t-1} / K_{i, t-2}$, as well as with measures of the cash stock. The results (unreported) are robust to this modification. One possible reason that firms manipulate earnings is to meet bond covenants; our results are also robust to including leverage as an additional explanatory variable.

We want to verify that the relation between discretionary accruals and investment is not hardwired. For example, firms with multiyear investment projects may pay for investment in advance. When doing so, firms will book future investment as a prepaid expense, a current asset. If so, current investment and discretionary accruals (the prepaid expense) may exhibit a positive correlation. Therefore, we reestimate the regression, now measuring normal accruals by using only accounts receivable in the definition of accruals. In that regression (not reported), the coefficient associated with the discretionary component of accounts receivable remains economically and statistically significant. We conclude that this hardwired link is not driving our result. 
In Table 2, Panel B provides additional investigation of the robustness of our results. Instead of including equity issuance as a control, we reestimate the regressions in Table 2, Panel A, by excluding all the companies that have positive equity issuance (Compustat Item 108). We find that all of our results continue to hold and are still generally statistically significant, even though the sample is now smaller by two-thirds. The effect of discretionary accruals on investment is still economically significant for firms that do not issue equity. A one-standard-deviation change in the level of discretionary accruals affects investment over capital by $1.5 \%$, which corresponds to $5 \%$ of the sample mean.

\subsection{Cross-sectional tests}

Our model suggests that the greater the opacity of the firm and the shorter the time horizon of the firm's shareholders, the more likely managers are to cater investments.

In Table 3, we explore these cross-sectional implications of our model. We use firm R\&D intensity as our proxy for firm transparency, based on the assumption that the resolution of all valuation uncertainty, which would necessarily eliminate any mispricing, takes longer for $R \& D$ projects than for other types of projects.

We first estimate our model for those firms that have data on R\&D. We report these results in column (1). Column (2) reestimates our baseline regression for those firms below the median value of $\mathrm{R} \& \mathrm{D}$ intensity. We note that we calculate medians yearly in order to isolate pure cross-sectional differences across firms. Column (3) shows the results for the subsample of firms with R\&D intensity above the median. Consistent with our model, we find economically important variation across the two subsamples. Firms that engage in a lot of R\&D invest more when they have a lot of discretionary accruals. The sensitivity of these firms' investment to discretionary accruals, 0.3154 , is almost two times as large as the sensitivity of firms that we argue are relatively more transparent.

The theory of catering investment relies on the assumption that either the shareholders or the manager of the firm have short-term horizons (Stein, 1996). Thus, our finding that discretionary accruals affect firm investment should be stronger for firms with a higher fraction of short-term investors. We test this hypothesis by using firm share turnover as our proxy for the relative amount of short-term investors trading a firm's stock. We measure turnover as the average, in December ${ }_{t-1}$, of the daily ratio of shares traded to shares outstanding at the end of the day, following Gaspar, Massa, and Matos (2005).

We first estimate our model for those firms that have data on turnover. We report these results in Table 3, column (4). Column (5) reestimates for each year our baseline regression for those firms with turnover below the yearly median, while column (6) reports the regression results for above-the-median firms. We find that the coefficient on discretionary accruals for high-turnover firms is 0.1726 , roughly $50 \%$ higher than the corresponding coefficient for firms with low turnover. 
Table 3

Discretionary accruals and firm investment: Cross-sectional analysis

Panel A

\begin{tabular}{|c|c|c|c|c|c|c|c|c|c|c|}
\hline & (1) & (2) & (3) & (4) & (5) & (6) & (7) & (8) & (9) & (10) \\
\hline$D A C C R_{i, t}$ & $\begin{array}{c}0.2455^{* * *} \\
(0.0345)\end{array}$ & $\begin{array}{c}0.1542^{* * *} \\
(0.0405)\end{array}$ & $\begin{array}{c}0.3052^{* * *} \\
(0.0533)\end{array}$ & $\begin{array}{c}0.1537^{* * * *} \\
(0.0283)\end{array}$ & $\begin{array}{l}0.1154^{* *} \\
(0.0501)\end{array}$ & $\begin{array}{c}0.1726^{* * *} \\
(0.0346)\end{array}$ & $\begin{array}{c}0.1584^{* * * *} \\
(0.0290)\end{array}$ & $\begin{array}{c}0.1572^{* * * *} \\
(0.0234)\end{array}$ & $\begin{array}{c}0.2927^{* * * *} \\
(0.0531)\end{array}$ & $\begin{array}{c}0.3433^{\text {*** }} \\
(0.0758)\end{array}$ \\
\hline$Q_{i, t-1}$ & $\begin{array}{c}0.0495^{* * * *} \\
(0.0062)\end{array}$ & $\begin{array}{c}0.0687^{* * *} \\
(0.0146)\end{array}$ & $\begin{array}{c}0.0461^{* * * *} \\
(0.0072)\end{array}$ & $\begin{array}{c}0.0454^{* * *} \\
(0.0079)\end{array}$ & $\begin{array}{c}0.0384^{* * * *} \\
(0.0077)\end{array}$ & $\begin{array}{c}0.0547^{* * * *} \\
(0.0095)\end{array}$ & $\begin{array}{c}0.0527^{* * *} \\
(0.0056)\end{array}$ & $\begin{array}{c}0.0529^{* * * *} \\
(0.0055)\end{array}$ & $\begin{array}{c}0.0532^{* * * *} \\
(0.0079)\end{array}$ & $\begin{array}{c}0.0483^{* * *} \\
(0.0100)\end{array}$ \\
\hline$C F_{i, t-1} / K_{i, t-2}$ & $\begin{array}{c}0.0694^{* * *} \\
(0.0100)\end{array}$ & $\begin{array}{c}0.1103^{* * *} \\
(0.0255)\end{array}$ & $\begin{array}{c}0.0597^{* * * *} \\
(0.0098)\end{array}$ & $\begin{array}{c}0.1042^{* * *} \\
(0.0172)\end{array}$ & $\begin{array}{c}0.1153^{* * *} \\
(0.0200)\end{array}$ & $\begin{array}{c}0.0918^{* * *} \\
(0.0224)\end{array}$ & $\begin{array}{c}0.0712^{* * * *} \\
(0.0082)\end{array}$ & $\begin{array}{c}0.0719^{* * * *} \\
(0.0082)\end{array}$ & $\begin{array}{c}0.0373^{* * *} \\
(0.0094)\end{array}$ & $\begin{array}{l}0.0221^{\text {** }} \\
(0.0092)\end{array}$ \\
\hline$\frac{E Q I S S_{i, t}}{K_{i, t-1}}$ & $\begin{array}{c}0.0241^{* * *} \\
(0.0074)\end{array}$ & $\begin{array}{c}0.0278 \\
(0.0178)\end{array}$ & $\begin{array}{c}0.0198^{* * *} \\
(0.0066)\end{array}$ & $\begin{array}{l}-0.0047 \\
(0.0071)\end{array}$ & $\begin{array}{l}-0.0091 \\
(0.0069)\end{array}$ & $\begin{array}{c}0.0060 \\
(0.0107)\end{array}$ & $\begin{array}{l}0.0129^{* *} \\
(0.0056)\end{array}$ & $\begin{array}{l}0.0129^{* *} \\
(0.0055)\end{array}$ & $\begin{array}{c}0.0162^{* * *} \\
(0.0061)\end{array}$ & $\begin{array}{c}0.0145 \\
(0.0118)\end{array}$ \\
\hline$H I G H D A C C R_{i, t}$ & & & & & & & $\begin{array}{c}0.0162^{* * * *} \\
(0.0058)\end{array}$ & & & \\
\hline highseo & & & & & & & & $\begin{array}{l}0.1684^{* *} \\
(0.0659)\end{array}$ & & \\
\hline Observations & 14838 & 7684 & 7154 & 16380 & 6796 & 9584 & 30490 & 30490 & 7776 & 3956 \\
\hline$R$-squared & 0.484 & 0.433 & 0.535 & 0.412 & 0.525 & 0.447 & 0.434 & 0.434 & 0.510 & 0.595 \\
\hline
\end{tabular}


Table 3

Continued

Panel B

\begin{tabular}{|c|c|c|c|c|c|c|c|c|c|}
\hline & (1) & (2) & (3) & (4) & (5) & (6) & (7) & (8) & (9) \\
\hline$D A C C R_{i, t}$ & $\begin{array}{c}0.1599^{* * *} \\
(0.0537)\end{array}$ & $\begin{array}{l}0.0941^{*} \\
(0.0540)\end{array}$ & $\begin{array}{l}0.2894^{* *} \\
(0.1219)\end{array}$ & $\begin{array}{l}0.0877^{*} \\
(0.0477)\end{array}$ & $\begin{array}{c}0.0279 \\
(0.0906)\end{array}$ & $\begin{array}{c}0.1593^{* * * *} \\
(0.0573)\end{array}$ & $\begin{array}{c}0.1211^{* * * *} \\
(0.0392)\end{array}$ & $\begin{array}{l}0.3917^{* *} \\
(0.1527)\end{array}$ & $\begin{array}{c}0.2409 \\
(0.2038)\end{array}$ \\
\hline$Q_{i, t-1}$ & $\begin{array}{l}0.0250^{* *} \\
(0.0100)\end{array}$ & $\begin{array}{c}0.0323^{* *} \\
(0.0140)\end{array}$ & $\begin{array}{c}0.0117 \\
(0.0158)\end{array}$ & $\begin{array}{c}0.0473^{* * *} \\
(0.0151)\end{array}$ & $\begin{array}{c}0.0399^{* * * *} \\
(0.0138)\end{array}$ & $\begin{array}{c}0.0593^{* *} \\
(0.0237)\end{array}$ & $\begin{array}{c}0.0442^{* * *} \\
(0.0108)\end{array}$ & $\begin{array}{l}0.0479^{* *} \\
(0.0203)\end{array}$ & $\begin{array}{l}0.1064^{* *} \\
(0.0493)\end{array}$ \\
\hline$C F_{i, t-1} / K_{i, t-2}$ & $\begin{array}{c}0.0828^{* * *} \\
(0.0147)\end{array}$ & $\begin{array}{c}0.0889^{\text {**** }} \\
(0.0219)\end{array}$ & $\begin{array}{c}0.0845^{* * * *} \\
(0.0218)\end{array}$ & $\begin{array}{c}0.0873^{* * * *} \\
(0.0190)\end{array}$ & $\begin{array}{c}0.1230^{* * * *} \\
(0.0350)\end{array}$ & $\begin{array}{c}0.0473^{* *} \\
(0.0196)\end{array}$ & $\begin{array}{c}0.0744^{* * * *} \\
(0.0140)\end{array}$ & $\begin{array}{c}0.0480 \\
(0.0724)\end{array}$ & $\begin{array}{c}0.0244 \\
(0.0676)\end{array}$ \\
\hline$H I G H D A C C R_{i, t}$ & & & & & & & $\begin{array}{c}0.0114 \\
(0.0083)\end{array}$ & & \\
\hline Observations & 4658 & 3061 & 1597 & 5959 & 3044 & 2915 & 10433 & 1841 & 821 \\
\hline$R$-squared & 0.430 & 0.445 & 0.447 & 0.433 & 0.468 & 0.615 & 0.427 & 0.569 & 0.650 \\
\hline
\end{tabular}

The dependent variable is the proportion of investment over beginning-of-year capital. High discretionary accruals, $H I G H D A C C R_{i, t-1}$, is a dummy equal to 1 if the firm has discretionary accruals in the top 20th percentile, and 0 otherwise. High equity issuance activity, HIGHEQISSUE $E_{i, t-1}$, is a dummy equal to 1 if the firm had equity issuance in the top 25 th percentile in the previous five years, and 0 otherwise. For a description of all the other variables, see the legend of Table 1. Panel A shows the results for the entire sample. All columns report coefficients and standard errors from OLS regressions. In Panel B, we repeat the same specification, but now we exclude companies that have positive equity issuance (Compustat Item 108). Column (1) shows results for the firms that have valid R\&D intensity data. Column (2) shows results for the firms that have below-median R\&D intensity. Column (3) shows results for those firms that have above-median R\&D intensity. Column (4) shows results for those firms that have valid firm share turnover data. Column (5) shows results for those firms that have below-median firm share turnover. Column (6) shows results for those firms that have above-median firm share turnover. We calculate medians on a year-by-year basis. Columns (7) and (8) show results for the whole sample. Column (9) shows results for the firm-years in the subperiod, 1995-2000. Column (10) shows results for the firm-years in the subperiod, 1998-2000. Columns (1)-(7) in Panel B correspond to columns (1)-(7) in Panel A. Columns (8)-(9) in Panel B correspond to columns (9)-(10) in Panel A. All regressions include firm- and year-fixed effects. The standard errors reported in parentheses are corrected for clustering of the residual at the firm level. Coefficients starred with one, two, and three asterisks are statistically significant at the $10 \%, 5 \%$, and $1 \%$ levels, respectively. 
Previous literature provides additional tests of our hypothesis based on subsample and cross-sectional evidence. We now explore these implications. Chan et al. (2001); and D'Avolio, Gildor, and Shleifer (2002) point out that the ability of discretionary accruals to predict negative stock returns is concentrated in the top $20 \%$ of firms ranked on accruals.

In Table 3, Panel A, column (7), we add a dummy, $H I G H D A C C R_{i, t}$, to our baseline discretionary accruals specification. The dummy takes the value of 1 if the firm is in the top $20 \%$ of firms based on discretionary accruals, and 0 otherwise. This dummy is significant at the $5 \%$ level of significance.

Teoh, Welch, and Wong (1998a) show that firms issuing equity who have the highest discretionary earnings have the lowest abnormal returns. In Table 3 , Panel A, column (8), we interact our discretionary accruals variable with a dummy, $\mathrm{HIGHSEO}_{i, t}$, that takes the value 1 if the firm is in the top $25 \%$ of equity issuance, as determined by Daniel and Titman's (2006) composite equity issuance variable. ${ }^{11}$ The coefficient is positive and has a $t$-statistic of 2.56 .

D'Avolio, Gildor, and Shleifer (2002) argue that in recent years, the marginal investor may have become less sophisticated, providing more incentives to distort earnings. In particular, they show that the mean discretionary accruals for the top decile has been increasing over the past 20 years, more than doubling since 1974 . Mean discretionary earnings for the top decile was close to $30 \%$ in 1999.

In Table 3, Panel A, column (9), we reestimate our baseline specification for the firm-years in the subperiod 1995-2000. The estimated coefficient on discretionary accruals is roughly two-thirds bigger, moving from 0.1987 to 0.2927 . Although we are left with only a quarter of the number of observations, the estimate is statistically significant at the $1 \%$ level. In column (10), we further restrict the sample to only those firm-years in the subperiod 19982000. Consistent with the hypothesis that manipulating earnings has become more effective, we find that the coefficient on discretionary accruals is more than $70 \%$ higher than in the baseline regression.

Panel B of Table 3 repeats our cross-sectional and subperiod tests of the catering hypothesis by restricting the sample to firms that do not have net positive cash flow from equity issuance. We find that our conclusions from Panel A do not change, even though we sometimes lose statistical power due to the reduction in size of the sample.

\subsection{Efficient or inefficient investment?}

So far, we have found a consistently strong positive correlation between our measures of mispricing and investment. According to the model, the positive correlation is due to the fact that overpriced firms take investment projects that

11 Following Daniel and Titman (2006), we construct a measure of a firm's equity issuance/repurchase activity, $S E O_{i, t}$, over a five-year period. We define $S E O_{i, t}$ as the log of the inverse of the percentage ownership in the firm one would have at time $t$, given a 1 firm at time $t-5$, assuming full reinvestment of all cash flows. 
have negative net present values. Similarly, underpriced firms forego investment projects with positive net present value. While the empirical results are consistent with inefficient allocation of resources in equilibrium, there are other potential explanations.

First, it is possible that firms with good investment opportunities manage earnings (i.e., generate high discretionary accruals) to manipulate their stock price, facilitating investment. The investment allocation in this case is efficient and temporary mispricing helps financially constrained firms make investments that they otherwise would not be able to make. This interpretation, though plausible, is not consistent with previous findings (e.g., Chan et al., 2001) that show that firms with abnormally soft earnings actually have relatively poor operating performance in subsequent years. Another potential explanation for our results is outlined in Dow and Gorton (1997). In that model, when the market has information that managers do not have, it is efficient for managers to make investment decisions taking into account stock prices. However, since discretionary accruals are set by the manager, this story seems unlikely to explain the relation between discretionary accruals and investment. Finally, our mispricing proxies may instead represent rational heterogeneity in discount rates. In this alternative explanation, firms with high discretionary accruals have low discount rates.

To distinguish between these alternative explanations, we measure the relation between investment and future stock returns. In our model, because firm business investment is linked to the market's misvaluation of the firm's equity, there is a negative relation between investment and subsequent risk-adjusted returns.

We estimate cross-sectional regressions of monthly stock returns on investment, Tobin's $Q$, and a control for cash-flow sensitivity, ${ }^{12}$

$$
R_{i, t}=a_{t}+b_{1, t} \ln \frac{I_{i, t-1}}{K_{i, t-2}}+b_{2, t} \ln Q_{i, t-1}+b_{3, t} \frac{C F_{i, t-1}}{K_{i, t-2}},
$$

where we measure returns in percentage units. The regression identifies crosssectional variation in returns, which is correlated with investment, and controls for investment opportunities and financial slack. Thus, the regression ties return predictability to firm investment behavior.

Unlike the previous sample in which we use only December-year-end firms, here we use all available data as long as there is a five-month lag between the month in which we are predicting returns and the fiscal year-end. We do this to ensure that the regression represents a valid trading rule. As in the previous sample, we eliminate firms with negative investment and/or otherwise extreme accounting ratios.

12 We are not the first looking at the relation between investment and returns. Titman, Wei, and Xie (2004) show that firms that spend more on capital investment relatively to their sales or total assets subsequently have negative benchmark-adjusted returns. See also Baker, Stein, and Wurgler (2003). 
As in Fama and MacBeth (1973), we average the time series of $b_{t}$ 's and report both the mean and the standard error of the mean estimate. Table 4, column (1), shows the result of estimating Equation (7). The coefficient on investment is -0.1579 with an associated $t$-statistic of 3.96. Consistent with our model, firms that overinvest (underinvest) on average have returns that are low (high).

We note that identification might be easier in this framework. In our previous investment regressions, controls for marginal profitability were critical for isolating variation in investment linked to mispricing. In theory, in these return regressions, we need only control for risk. Table 4, column (2), includes three firm characteristics that are associated with cross-sectional differences in average returns that may or may not be associated with risk: firm size (market capitalization), firm book-to-market equity, and firm momentum. These characteristics are known anomalies that we want to control for. Our results confirm the results of previous studies: book-to-market equity and firm momentum predict returns with a positive coefficient, while size has a negative coefficient. ${ }^{13}$ More importantly, these controls do not subsume the investment effect, since the relevant coefficient drops less than two basis points and remains quite statistically significant. We also include the control variable for equity issuance, $\frac{E Q I S S_{i, t-1}}{K_{i, t-2}}$. Consistent with previous research, we find that firms issuing equity subsequently underperform.

Our model predicts that this return predictability we document should be stronger for firms facing a greater degree of information asymmetry and/or having investors with shorter horizons. In Table 4, we test these predictions by estimating the degree of return predictability linked to abnormal investment for high R\&D-intensity and high share-turnover firms. In column (3), we reestimate the relation between investment and subsequent stock returns for those firms with available R\&D data each year. In column (4), we reestimate the relation by including an interaction variable between investment and an above-median R\&D dummy variable. The regression shows that the abnormal-investment effect in the cross-section of average returns is mainly in high R\&D firms. The $t$-statistic on this interaction term is 3.35. The ability of investment to predict crosssectional differences in returns is not statistically significant for low R\&D firms.

In column (5) of Table 4, we reestimate the full regression for those firms with available share turnover data, and in column (6) we reestimate the relation by using an interaction term between above-median share turnover and investment. For the full sample of firms with available turnover data, the abnormal investment effect is less strong. In fact, the coefficient is not statistically significant.

As noted earlier, our model predicts that the effect will be stronger for those firms with above-median turnover. We find results consistent with our model:

13 Though one might initially think that using $Q$ and $B E / M E$ in the same regression might be problematic, it turns out that the two variables are not so highly correlated as to cause multicollinearity problems. Nevertheless, we have checked to make sure that our results are not sensitive to the decision to include both variables in the regression. 
Table 4

Investment and future stock returns

Panel A

\begin{tabular}{|c|c|c|c|c|c|c|c|c|c|}
\hline & (1) & (2) & (3) & (4) & (5) & (6) & (7) & (8) & (9) \\
\hline Intercept & $\begin{array}{c}1.359^{* * *} \\
(0.354)\end{array}$ & $\begin{array}{c}3.632^{* * *} \\
(0.788)\end{array}$ & $\begin{array}{c}4.252^{* * * *} \\
(0.895)\end{array}$ & $\begin{array}{c}4.088^{* * *} \\
(0.868)\end{array}$ & $\begin{array}{c}2.308^{* * * *} \\
(0.796)\end{array}$ & $\begin{array}{c}2.375^{* * *} \\
(0.815)\end{array}$ & $\begin{array}{c}3.636^{* * * *} \\
(0.790)\end{array}$ & $\begin{array}{l}3.693^{* * *} \\
(0.782)\end{array}$ & $\begin{array}{l}3.608^{* * * *} \\
(0.772)\end{array}$ \\
\hline $\ln I_{i, t-1} / K_{i, t-2}$ & $\begin{array}{c}-0.156^{* * *} \\
(0.041)\end{array}$ & $\begin{array}{l}-0.143^{* * *} \\
(0.036)\end{array}$ & $\begin{array}{c}-0.123^{* * *} \\
(0.052)\end{array}$ & $\begin{array}{c}0.005 \\
(0.075)\end{array}$ & $\begin{array}{l}-0.074 \\
(0.049)\end{array}$ & $\begin{array}{l}-0.029 \\
(0.061)\end{array}$ & $\begin{array}{c}-0.145^{* * *} \\
(0.037)\end{array}$ & $\begin{array}{l}-0.216^{* * *} \\
(0.043)\end{array}$ & $\begin{array}{c}-0.092^{* *} \\
(0.041)\end{array}$ \\
\hline $\ln I_{i, t-1} / K_{i, t-2}^{*} H I G H R D$ & & & & $\begin{array}{c}-0.285^{* * *} \\
(0.085)\end{array}$ & & & & & \\
\hline $\ln I_{i, t-1} / K_{i, t-2}^{*} H I G H T U R N$ & & & & & & $\begin{array}{c}-0.115^{* *} \\
(0.052)\end{array}$ & & & \\
\hline $\ln I_{i, t-1} / K_{i, t-2}^{*} H I G H K Z$ & & & & & & & & $\begin{array}{l}0.108^{* * *} \\
(0.031)\end{array}$ & \\
\hline $\ln Q_{i, t-1}$ & $\begin{array}{l}-0.408^{* * *} \\
(0.126)\end{array}$ & $\begin{array}{l}0.280^{* *} \\
(0.124)\end{array}$ & $\begin{array}{l}0.269^{* *} \\
(0.133)\end{array}$ & $\begin{array}{l}0.213^{*} \\
(0.129)\end{array}$ & $\begin{array}{c}0.043 \\
(0.171)\end{array}$ & $\begin{array}{c}0.069 \\
(0.170)\end{array}$ & $\begin{array}{l}0.293^{* *} \\
(0.127)\end{array}$ & $\begin{array}{l}0.273^{* *} \\
(0.125)\end{array}$ & $\begin{array}{c}0.148 \\
(0.132)\end{array}$ \\
\hline $\ln C F_{i, t-1} / K_{i, t-2}$ & $\begin{array}{c}0.012 \\
(0.038)\end{array}$ & $\begin{array}{l}-0.008 \\
(0.030)\end{array}$ & $\begin{array}{c}0.021 \\
(0.038)\end{array}$ & $\begin{array}{l}0.030 \\
(0.037)\end{array}$ & $\begin{array}{c}0.007 \\
(0.046)\end{array}$ & $\begin{array}{c}0.011 \\
(0.046)\end{array}$ & $\begin{array}{l}-0.018 \\
(0.033)\end{array}$ & $\begin{array}{l}-0.021 \\
(0.033)\end{array}$ & $\begin{array}{l}-0.002 \\
(0.040)\end{array}$ \\
\hline$E Q I S S_{i, t-1} / K_{i, t-2}$ & $\begin{array}{l}-0.422^{* *} \\
(0.201)\end{array}$ & $\begin{array}{l}-0.472^{* * *} \\
(0.195)\end{array}$ & $\begin{array}{c}-0.727^{* * *} \\
(0.315)\end{array}$ & $\begin{array}{l}-0.744^{* * *} \\
(0.314)\end{array}$ & $\begin{array}{l}-0.200 \\
(0.247)\end{array}$ & $\begin{array}{l}-0.253 \\
(0.244)\end{array}$ & $\begin{array}{l}-0.446^{* *} \\
(0.204)\end{array}$ & $\begin{array}{c}-0.453^{* *} \\
(0.198)\end{array}$ & $\begin{array}{l}-0.386 \\
(0.311)\end{array}$ \\
\hline $\ln M E_{i, t-1}$ & & $\begin{array}{c}-0.209^{* * *} \\
(0.055)\end{array}$ & $\begin{array}{c}-0.241^{* * *} \\
(0.061)\end{array}$ & $\begin{array}{c}-0.222^{* * *} \\
(0.058)\end{array}$ & $\begin{array}{c}-0.100^{*} \\
(0.051)\end{array}$ & $\begin{array}{c}-0.106^{*} \\
(0.052)\end{array}$ & $\begin{array}{c}-0.210^{* * *} \\
(0.055)\end{array}$ & $\begin{array}{c}-0.215^{* * *} \\
(0.054)\end{array}$ & $\begin{array}{c}-0.197^{* * *} \\
(0.054)\end{array}$ \\
\hline $\ln B E / M E_{i, t-1}$ & & $\begin{array}{c}0.332^{* * * *} \\
(0.078)\end{array}$ & $\begin{array}{c}0.392^{* * * *} \\
(0.095)\end{array}$ & $\begin{array}{c}0.417^{* * * *} \\
(0.093)\end{array}$ & $\begin{array}{c}0.177 \\
(0.108)\end{array}$ & $\begin{array}{l}0.194^{*} \\
(0.106)\end{array}$ & $\begin{array}{c}0.329^{* * *} \\
(0.079)\end{array}$ & $\begin{array}{c}0.323^{* * * *} \\
(0.080)\end{array}$ & $\begin{array}{l}0.192^{* *} \\
(0.088)\end{array}$ \\
\hline $\ln M O M_{i, t-1}$ & & $\begin{array}{c}0.672^{* * * *} \\
(0.198)\end{array}$ & $\begin{array}{l}0.475^{\text {** }} \\
(0.216)\end{array}$ & $\begin{array}{l}0.434^{* *} \\
(0.213)\end{array}$ & $\begin{array}{c}0.908^{* * * *} \\
(0.227)\end{array}$ & $\begin{array}{c}0.900^{* * * *} \\
(0.221)\end{array}$ & $\begin{array}{c}0.686^{* * * *} \\
(0.199)\end{array}$ & $\begin{array}{c}0.678^{* * * *} \\
(0.198)\end{array}$ & $\begin{array}{c}0.690^{* * * *} \\
(0.206)\end{array}$ \\
\hline$D A C C R_{i, t-1}$ & & & & & & & & & $\begin{array}{c}-0.599^{* *} \\
(0.268)\end{array}$ \\
\hline Observations & 456 & 456 & 456 & 456 & 444 & 444 & 456 & 456 & 336 \\
\hline
\end{tabular}


Table 4

Continued

Panel B

\begin{tabular}{|c|c|c|c|c|c|c|c|c|c|}
\hline & (1) & (2) & (3) & (4) & (5) & (6) & (7) & (8) & (9) \\
\hline Intercept & $\begin{array}{c}1.517^{* * * *} \\
(0.336)\end{array}$ & $\begin{array}{c}3.980^{* * * *} \\
(0.766)\end{array}$ & $\begin{array}{c}4.504^{* * *} \\
(0.940)\end{array}$ & $\begin{array}{c}4.405^{* * *} \\
(0.904)\end{array}$ & $\begin{array}{c}2.315^{* * * *} \\
(0.828)\end{array}$ & $\begin{array}{c}2.482^{* * *} \\
(0.852)\end{array}$ & $\begin{array}{c}3.986^{* * *} \\
(0.771)\end{array}$ & $\begin{array}{c}4.011^{* * *} \\
(0.760)\end{array}$ & $\begin{array}{l}3.645^{* * *} \\
(0.759)\end{array}$ \\
\hline $\ln I_{i, t-1} / K_{i, t-2}$ & $\begin{array}{c}-0.136^{* * *} \\
(0.041)\end{array}$ & $\begin{array}{c}-0.141^{* * *} \\
(0.040)\end{array}$ & $\begin{array}{c}-0.145^{*} \\
(0.078)\end{array}$ & $\begin{array}{l}-0.089 \\
(0.079)\end{array}$ & $\begin{array}{c}-0.143^{* * *} \\
(0.059)\end{array}$ & $\begin{array}{l}-0.082 \\
(0.065)\end{array}$ & $\begin{array}{l}-0.135^{* * *} \\
(0.040)\end{array}$ & $\begin{array}{l}-0.172^{* * *} \\
(0.047)\end{array}$ & $\begin{array}{l}-0.142^{* * *} \\
(0.047)\end{array}$ \\
\hline $\ln I_{i, t-1} / K_{i, t-2}^{*} H I G H R D$ & & & & $\begin{array}{c}-0.150^{*} \\
(0.088)\end{array}$ & & & & & \\
\hline $\ln I_{i, t-1} / K_{i, t-2}^{*} H I G H T U R N$ & & & & & & $\begin{array}{l}-0.154^{* * *} \\
(0.059)\end{array}$ & & & \\
\hline $\ln I_{i, t-1} / K_{i, t-2}^{*} H I G H K Z$ & & & & & & & & $\begin{array}{c}0.051 \\
(0.040)\end{array}$ & \\
\hline $\ln Q_{i, t-1}$ & $\begin{array}{c}-0.409^{* * *} \\
(0.125)\end{array}$ & $\begin{array}{l}0.370^{* *} \\
(0.177)\end{array}$ & $\begin{array}{c}0.308 \\
(0.254)\end{array}$ & $\begin{array}{c}0.293 \\
(0.255)\end{array}$ & $\begin{array}{c}0.402 \\
(0.272)\end{array}$ & $\begin{array}{l}0.417 \\
(0.270)\end{array}$ & $\begin{array}{l}0.345^{*} \\
(0.183)\end{array}$ & $\begin{array}{l}0.315^{*} \\
(0.182)\end{array}$ & $\begin{array}{c}0.125 \\
(0.199)\end{array}$ \\
\hline $\ln C F_{i, t-1} / K_{i, t-2}$ & $\begin{array}{l}-0.017 \\
(0.046)\end{array}$ & $\begin{array}{l}-0.011 \\
(0.040)\end{array}$ & $\begin{array}{c}0.015 \\
(0.071)\end{array}$ & $\begin{array}{c}0.013 \\
(0.071)\end{array}$ & $\begin{array}{c}0.016 \\
(0.066)\end{array}$ & $\begin{array}{c}0.018 \\
(0.066)\end{array}$ & $\begin{array}{l}-0.062 \\
(0.048)\end{array}$ & $\begin{array}{l}-0.059 \\
(0.047)\end{array}$ & $\begin{array}{l}0.111^{*} \\
(0.061)\end{array}$ \\
\hline $\ln M E_{i, t-1}$ & & $\begin{array}{l}-0.244^{* * *} \\
(0.058)\end{array}$ & $\begin{array}{l}-0.272^{* * *} \\
(0.068)\end{array}$ & $\begin{array}{c}-0.262^{* * * *} \\
(0.065)\end{array}$ & $\begin{array}{l}-0.104^{*} \\
(0.057)\end{array}$ & $\begin{array}{l}-0.118^{* *} \\
(0.058)\end{array}$ & $\begin{array}{l}-0.241^{* * *} \\
(0.058)\end{array}$ & $\begin{array}{l}-0.245^{* * *} \\
(0.057)\end{array}$ & $\begin{array}{l}-0.212^{* * *} \\
(0.057)\end{array}$ \\
\hline $\ln B E / M E_{i, t-1}$ & & $\begin{array}{c}0.322^{* * * *} \\
(0.098)\end{array}$ & $\begin{array}{c}0.364^{* * * *} \\
(0.145)\end{array}$ & $\begin{array}{c}0.388^{* * * *} \\
(0.145)\end{array}$ & $\begin{array}{c}0.351^{* * * *} \\
(0.142)\end{array}$ & $\begin{array}{c}0.367^{* * * *} \\
(0.141)\end{array}$ & $\begin{array}{c}0.301^{* * * *} \\
(0.100)\end{array}$ & $\begin{array}{c}0.287^{* * * *} \\
(0.100)\end{array}$ & $\begin{array}{l}0.204^{*} \\
(0.113)\end{array}$ \\
\hline $\ln M O M_{i, t-1}$ & & $\begin{array}{c}0.309 \\
(0.196)\end{array}$ & $\begin{array}{l}-0.025 \\
(0.230)\end{array}$ & $\begin{array}{l}-0.046 \\
(0.230)\end{array}$ & $\begin{array}{l}0.493^{*} \\
(0.257)\end{array}$ & $\begin{array}{l}0.462^{*} \\
(0.253)\end{array}$ & $\begin{array}{c}0.306 \\
(0.198)\end{array}$ & $\begin{array}{c}0.299 \\
(0.196)\end{array}$ & $\begin{array}{c}0.335 \\
(0.211)\end{array}$ \\
\hline$D A C C R_{i, t-1}$ & & & & & & & & & $\begin{array}{l}-0.441 \\
(0.414)\end{array}$ \\
\hline Observations & 456 & 456 & 456 & 456 & 444 & 444 & 456 & 456 & 336 \\
\hline
\end{tabular}

The table reports the results from Fama-MacBeth (1973) cross-sectional monthly stock-return regressions. The independent variables include investment over beginning-of-year capital,

Tobin's $O$, cash flow, book-to-market equity, firm size, price momentum, discretionary accruals, and equity issuance. For a description of the variables, see the legend of Table 1 . Columns (1), (2), and (9) show results for the whole sample. The pairs of columns (3) and (4), (5) and (6), and (7) and (8) show results for the sample of firms with valid research and development, share turnover, and Kaplan-Zingales (1997) index data, respectively. Column (4) includes an interaction between investment and a dummy for those firms that have above-median research and development intensity. Column (6) includes an interaction between investment and a dummy for those firms that have above-median firm share turnover. Column (8) includes an interaction between investment and a dummy for those firms that have above-median values of the Kaplan-Zingales (1997) index. In Panel B, we repeat the same specification, but now we exclude companies that have positive equity issuance (Compustat Item 108). Standard errors are reported in parentheses. Coefficients starred with one, two, and three asterisks are 
the coefficient on investment for high-turnover firms is more than four times more negative than that for the entire sample, and it is statistically significant with a $t$-statistic of 2.21. Firms with low share turnover have a coefficient on investment that is not statistically significant from zero.

We emphasize that the above results are very important for one's interpretation. It is always possible to claim that all of the predictive power of investment is due to cross-sectional variation in discount rates. ${ }^{14}$ However, there is no natural explanation as to why variation in those discount rates is primarily found in firms with above-median R\&D and above-median turnover.

In Table 4, columns (7) and (8), we split the sample according to firms' Kaplan and Zingales (1997) index of financial constraints. We construct the index using Kaplan and Zingales's (1997) regression coefficients and five accounting ratios. The Kaplan and Zingales index is higher for firms that are more constrained. The five variables, along with the signs of their coefficients in the Kaplan and Zingales index, are cash flow to total capital (negative), the market-to-book ratio (positive), debt to total capital (positive), dividends to total capital (negative), and cash holdings to capital (negative). We provide additional information on the construction of this index in the Appendix.

The reason we split the sample according to firms' degrees of financial constraints is because doing so distinguishes our model, in which unconstrained firms may invest in negative NPV projects when overpriced, from other models, in which financially constrained firms are able to invest more efficiently when overpriced. In column (7) of Table 4, we estimate the relation between investment and subsequent stock returns for the sample of firms with available data for the Kaplan and Zingales (1997) index. Column (8) includes an interaction between investment and an above-median Kaplan and Zingales index dummy variable. We find that the coefficient of returns on investment is higher for firms with an above-median Kaplan and Zingales index, and that the difference is statistically significant. However, the coefficient on investment for firms with a below-median Kaplan and Zingales index is -0.216 ( $t$-statistic of 5.02), compared to -0.145 for the entire sample. The investment of unconstrained firms still predicts negative future returns. This effect is extremely strong, both economically and statistically.

In the final regression, in column (9) of Table 4, we add our mispricing proxy from the previous section, discretionary accruals, to the right-hand side. If the ability of discretionary accruals to explain investment actually works through a mispricing channel rather than a profitability channel, then we should see the coefficient on investment move closer to zero. The results confirm this hypothesis. Earlier, the coefficient on investment for the full sample was -0.136 . After including our two mispricing proxies, that coefficient drops by almost $50 \%$ to -0.092 . At the same time, the coefficient on discretionary

14 For example, Cochrane (1991) finds that investment has significant forecasting power for aggregate stock returns. Lamont (2000) documents that planned investment has substantial forecasting power at both the aggregate and industry level. Both authors argue that their findings are consistent with variation in discount rates. 
accruals is statistically significant. This result helps tie our analysis together by linking the previous investment- $Q$ regressions with these return predictability regressions in a manner consistent with our model. ${ }^{15}$

\subsection{Time variation in investment catering}

If sentiment drives the investment decisions of corporate managers, then investment should be sensitive to the degree to which investors are overexuberant about the firm's prospects. In other words, when $\alpha$ is extremely high, we should see an especially large amount of overinvestment. Here we identify high $\alpha$, using time-series variation in market valuations. ${ }^{16}$ Each month, we sort firms into abnormal investment quintiles (we will define abnormal investment carefully below). We then measure the (abnormal) investment premium as the difference between the equal-weight price-to-book ratio of the top and bottom quintile.

We use this investment premium in two time-series regressions. We first forecast the subsequent change in abnormal investment, $I^{a}$, across the high and low quintiles,

$$
\begin{aligned}
\left(I_{H, t+1}^{a}-I_{L, t+1}^{a}\right)-\left(I_{H, t}^{a}-I_{L, t}^{a}\right)= & g_{0}+g_{1}\left(\frac{M E}{B E_{H, t}}-\frac{M E}{B E_{L, t}}\right) \\
& +g_{2}\left(I_{H, t}^{a}-I_{L, t}^{a}\right)+\varepsilon_{I^{a}, t+1} .
\end{aligned}
$$

If the spread in current valuations across high and low-abnormal investment firms is particularly high, we expect a particularly strong increase in the spread in abnormal investment if managers are actually catering to market sentiment. We include in the regression the current spread in abnormal investment as an additional control, as there may be mean reversion due to adjustment costs.

We then use the investment premium to predict future abnormal returns in a four-factor time-series regression. Our regression controls for the market, size, and book-to-market factors of Fama and French (1993) and the momentum

15 A potential problem with this result is that if $Q$ is measured with error, the regression coefficients may be biased. We tried to apply the Erickson and Whited (2002) high-order moment estimators to our larger, longer sample. However, use of these estimators requires first passing a test of the model's two identifying assumptions: (i) $Q$ predicts future returns, controlling for other variables and (ii) the residuals in a linear regression of $Q$ on these control variables are skewed. Even for the simplest specification in column (1), we are unable to reject the null hypothesis implied by the model's identifying assumptions for half of the cross-sections. For the other specifications which include book-to-market equity as a control variable, more than $75 \%$ of the cross-sections fail the Erickson-Whited identification test. In both cases, OLS estimates are statistically insignificant for the cross-sections that pass the Erickson-Whited identification test. This suggests that any failure to reject the null hypothesis using their estimator on those cross-sections may simply be due to a lack of power.

16 This approach is related to recent studies that examine the effect of sentiment on managers' actions. For example, Cooper, Dimitrov, and Rau (2001) document that many firms added a .com to their corporate name as internet valuations (and presumably sentiment) rose. Correspondingly, Cooper et al. (2005) show that firms deleted the .com suffix from their name once internet valuations started to decline (and irrational exuberance presumably subsided). More generally, Baker and Wurgler (2004) provide evidence consistent with corporate dividend policy being driven by a time-varying preference among investors for firm payouts. They show that the difference in price between payers and nonpayers has information about the magnitude of the sentiment premium driving short-term catering incentives. In particular, this premium predicts both future payout policy (positively) and subsequent returns (negatively). Like Baker and Wurgler (2004), we follow Cohen, Polk, and Vuolteenaho (2003) and use the spread in value ratios across portfolios to predict their subsequent return. 
factor of Carhart (1997) as follows:

$$
\begin{aligned}
R_{H, t}+1-R_{L, t+1}= & \alpha_{0}+\alpha_{1}\left(\frac{M E}{B E_{H, t}}-\frac{M E}{B E_{L, t}}\right)+b R M R F+s S M B \\
& +h H M L+m M O M+\varepsilon_{R, t+1} .
\end{aligned}
$$

Under the catering theory, abnormal investment is negatively correlated with future stock returns. In our regression, $\alpha_{0}$ measures the extent to which that is true, on average, while $\alpha_{1}$ measures the extent to which that is especially true when the investment premium is relatively high.

The key input to our analysis is how we define abnormal investment. We first measure normal investment using industry medians. Our industry adjustment is based on Ken French's 48 industry definitions (available on his web site at http://mba.tuck.dartmouth.edu/pages/faculty/ ken.french/data_library.html). We form the relevant industry portfolios for each year and measure the median investment/capital ratio for each industry. We then define industry-adjusted investment as the difference between a firm's investment/capital ratio and its industry's median.

Since profitability almost certainly varies within industries, we use additional controls for profitability. We could adjust investment through a Tobin's $Q$ regression, as done earlier in the paper. However, our approach only requires very coarse ordinal measures of abnormal investment (i.e., whether a firm is in the top or bottom quintile). Therefore, we measure abnormal investment as the residual in a cross-sectional regression of industry-adjusted investment on various rank-transformed firm characteristics that Fama and French (2000) link to profitability. We describe those measures in the Appendix.

Table 5 reports the results for those two time-series regressions. Since we form the left-hand-side variable in the first regression from information that only changes annually, we expect some degree of autocorrelation in the errors and thus report Newey-West (1987) $t$-statistics adjusted for 11 lags. We know that for the return-forecasting regression, the small-sample $p$-values obtained from the usual student $t$-test tend to over-reject the null (Stambaugh, 1999) when the forecasting variable is persistent with shocks that are negatively correlated with return shocks. However, in our case, our forecasting variable has a much lower persistence (an AR(1) coefficient of 0.9, not reported) than, for example, the dividend yield. Moreover, shocks to the investment premium variable are positively correlated with the return shocks. Therefore, since the size distortion is minimal, we report OLS $t$-statistics for the second regression. ${ }^{17}$

We find evidence of catering effects using this approach. We first investigate whether the investment premium forecasts subsequent changes in abnormal investment. The coefficient is 0.0238 with an associated $t$-statistic of 1.63 , which rejects the null hypothesis that the coefficient is less than or equal to

17 We have confirmed that there is no size distortion in our hypothesis tests using the conditional-critical-value function of Polk, Thompson, and Vuolteenaho (2006). 
Table 5

Time-varying catering effects

\begin{tabular}{lcc}
\hline Intercept & -0.0005 & $-0.4520^{* * *}$ \\
& $(0.0951)$ & $(0.0584)$ \\
$M E / B E_{H, t}-M E / B E_{L, t}$ & $0.0238^{*}$ & $-0.1701^{* * *}$ \\
& $(0.0146)$ & $(0.0726)$ \\
$I_{H, t}-I_{L, t}$ & $-0.5700^{* * *}$ & \\
& $(0.0443)$ & $0.0653^{* * *}$ \\
& & $(0.0139)$ \\
& & $0.0827^{* * *}$ \\
$S M B_{t+1}$ & & $(0.0180)$ \\
& & $-0.2240^{* * *}$ \\
$H M L_{t+1}$ & & $(0.0211)$ \\
$M O M_{t+1}$ & & $-0.0539^{* * *}$ \\
& & $(0.0144)$ \\
Observations & & 456 \\
$R$-squared & 456 & .404 \\
\hline
\end{tabular}

This table reports the results from two time-series regressions that link future changes in abnormal investment and future abnormal stock returns to the abnormal-investment premium, $\frac{M E}{B E}{ }_{H, t}-\frac{M E}{B E} L, t$. We define the abnormalinvestment premium as the spread in the market-to-book equity ratio across the top and bottom quintile of stocks sorted each month on abnormal investment. We define abnormal investment as follows. We first measure the industry-adjusted investment as firm-level investment/capital ratios adjusted by industry medians. Industry definitions are the 48 industries as defined on Ken French's website. We then orthogonalize industry-adjusted investment to six rank-transformed measures of firm profitability, described in the Appendix. We define abnormal investment, $I^{a}$, as the residual in that regression. We report estimates of the following regressions in columns (1) through (2), respectively:

$$
\begin{gathered}
\left(I_{H, t+1}^{a}-I_{L, t+1}^{a}\right)-\left(I_{H, t}^{a}-I_{L, t}^{a}\right)=g_{0}+g_{1}\left(\frac{M E}{B E}_{H, t}-\frac{M E}{B E}_{L, t}\right)+g_{2}\left(I_{H, t}^{a}-I_{L, t}^{a}\right)+\varepsilon_{I^{a}, t+1} \\
R_{H, t+1}-R_{L, t+1}=\alpha_{0}+\alpha_{1}\left(\frac{M E}{B E}_{H, t}-\frac{M E}{B E_{L, t}}\right)+b R M R F+s S M B+h H M L+m M O M+\varepsilon_{R, t+1} .
\end{gathered}
$$

We first demean the abnormal-investment premium for the sake of interpretation. We report standard errors in parentheses. In column (1), the standard errors are Newey-West-adjusted (with 11 lags). Coefficients starred with one, two, and three asterisks are statistically significant at the $10 \%, 5 \%$, and $1 \%$ levels, respectively.

zero at the $10 \%$ level of significance. Though we can just measure a relation, the effect is weak as roughly only $3 \%$ of the variation in changes in the abnormal investment can be linked to independent variation in the investment premium.

We then show that the investment premium also forecasts future risk-adjusted stock returns. Not only do high-abnormal investment firms underperform lowabnormal investment firms by 45 basis points a month (with a $t$-statistic of -7.75), they particularly underperform when the investment premium is high. In fact, the estimate of the forecasting coefficient is -0.1701 , which rejects the null hypothesis at the $2 \%$ level of significance (associated $t$-statistic of -2.34).

Figure 1 plots the conditional alpha for this abnormal-investment difference portfolio. As the figure shows, although there is considerable variation in the expected abnormal return, we can always expect high-abnormal investment firms to underperform low-abnormal investment firms. At the end of May 1999, the conditional alpha reaches its lowest value, -1.29 basis points per month, almost three times higher than the average underperformance. 


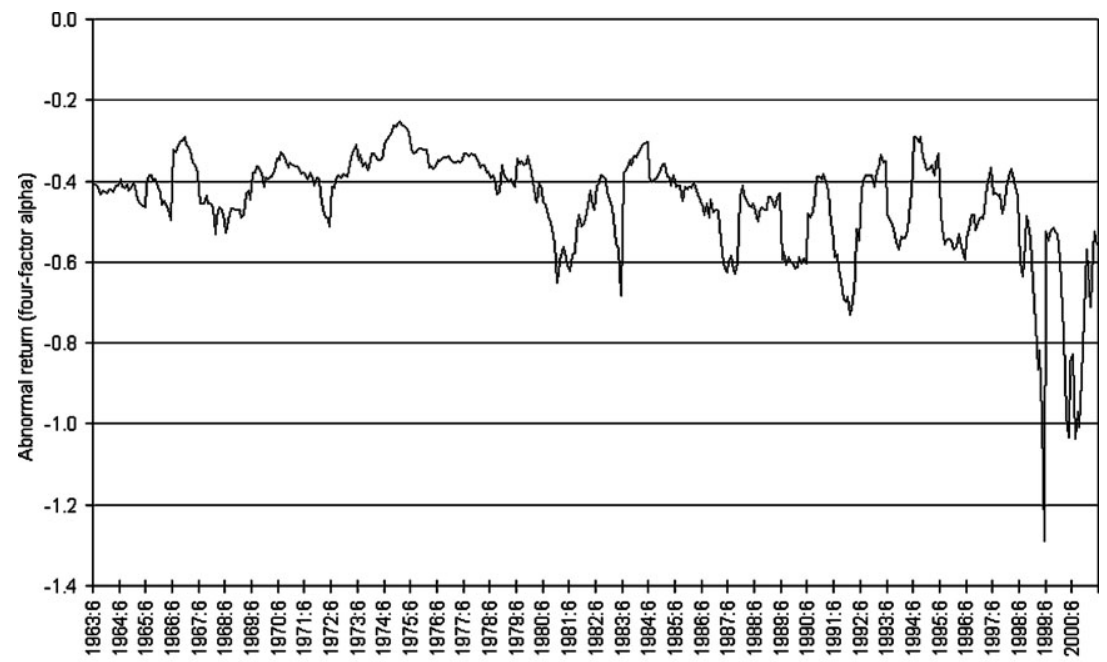

Month: June 1963 to May 2001

Figure 1

Time-varying catering effects

This figure shows the evolution of conditional alpha based on the regression in column (2) of Table 5,

$$
R_{H, t+1}-R_{L, t+1}=\alpha_{0}+\alpha_{1}\left(\frac{M E}{B E_{H, t}}-\frac{M E}{B E_{L, t}}\right)+b R M R F+s S M B+h H M L+m M O M+\varepsilon_{R, t+1},
$$

which uses the spread in price-to-book across abnormal investment quintiles to predict the four-factor abnormal return on the abnormal-investment difference portfolio.

\section{Conclusions}

We present a framework based on Stein (1996) in which we show that a firm's investment decision is affected by market (mis)valuation of the company, even if new investment projects are not financed by new equity. If investors have short horizons, managers will rationally choose to invest in projects that are overpriced and avoid projects that are underpriced, thus catering to sentiment in order to maximize near-term stock prices.

In the empirical part of the paper, we show that that when we control for investment opportunities and financial slack, variables that predict relatively low stock returns are positively correlated with investment. We show that as a percentage of capital, a typical change in our mispricing proxy results in roughly a $2 \%$ change in the firm's investment. Our model predicts that the greater the degree of asymmetric information between firms and investors, the greater should be these sensitivities. We find that is the case, as the effect is weaker for firms with relatively low R\&D intensity.

Our model also predicts that the effects should be stronger for firms with short-term investors. We find that this is also true, as the effect is stronger for firms with relatively high share turnover. 
The thrust of these results are generally consistent with Chirinko and Schaller (2001) and Baker, Stein, and Wurgler (2003), where sentiment also affects real investment. However, our results differ as the influence of sentiment on real investment works through a catering rather than an equity issuance channel.

We also show that patterns in the cross-section of average returns are consistent with those patterns in investment: firms with shorter shareholder horizons, and those whose assets are more difficult to value, cater more. When we control for investment opportunities and other characteristics linked to return predictability, we find that firms with high (low) investment have low (high) subsequent stock returns, and that this relation is stronger for firms with above-median R\&D intensity or above-median turnover.

Our main interpretation of the results is consistent with Stein's (1996) hypothesis that short-horizon managers temporarily distort the firm's investment decision and therefore misallocate resources. An alternative interpretation is that our mispricing proxies measure unobserved (to the econometrician) rational variation in discount rates. On the one hand, stories explaining discretional accruals as a proxy for risk seem difficult, but on the other hand, it is puzzling that market forces do not discipline these investors' biases. Nonetheless, our results provide a striking empirical regularity that associates firms' investment decisions with a characteristic that apparently predicts future risk-adjusted returns.

Finally, our paper focuses on just one important capital allocation decision. However, we could study other corporate decisions, such as hiring employees or engaging in acquisition activity within this context. For example, Shleifer and Vishny (2003) argue that the cost of equity is a strong determinant of merger activity. Evidence consistent with this alternative channel is reported in Rhodes-Kropf, Robinson, and Viswanathan (2004).

\section{Appendix}

Investment $\left(I_{t}\right)$ is capital expenditure (Compustat Item 128). Capital $\left(K_{t-1}\right)$ is net property, plant, and equipment (Compustat Item 8). $Q_{t-1}$ equals the market value of assets divided by the book value of assets (Compustat Item 6). The market value of assets equals the book value of assets plus the market value of common stock less the sum of book value of common stock (Compustat Item 6) and balance sheet deferred taxes (Compustat Item 74) in year $t-1$. Cash flow $\left(C F_{t-1}\right)$ equals the sum of earnings before extraordinary items (Compustat Item 18) and depreciation (Compustat Item 14) over beginning-of-year capital. Sales (Compustat Item 12) is net sales. The one-year expected profitability $\left(E_{t-1}\left[R O A_{t}\right]\right)$ is the median analyst year $t-1$ forecast of earnings in year $t$ divided by the book value of assets (Compustat Item 6). The two-year expected profitability $\left(E_{t-1}\left[R O A_{t+1}\right]\right)$ is the median analyst year $t-1$ forecast of earnings in year $t+1$ divided by the book value of assets (Compustat Item 6) in year $t-1$. The five-year expected profitability $\left(E_{t-1}\left[R_{0 A} A_{t+4}\right]\right)$ is the median analyst year $t-1$ forecast of earnings in year $t+4$ divided by the book value of assets (Compustat Item 6) in year $t-1$. R\&D intensity is R\&D expense (Compustat Item 46) over the book value of assets (Compustat Item 6). We ignore firms with negative accounting numbers for book assets, capital, or investment. Because the observations probably represent data errors, we drop those firms that have extreme values for the accounting ratios we study. 
We construct discretionary accruals following Chan et al. (2001). Accruals $\left(A C C R_{t}\right)$ equal the change in accounts receivable (Compustat Item 2) plus the change in inventories (Compustat Item 3 ) plus the change in other current assets (Compustat Item 68) minus the change in accounts payable (Compustat Item 70) minus the change in other current liabilities (Compustat Item 72) minus depreciation (Compustat Item 178). We scale accruals by total assets (the average of Compustat Item 6 at the beginning and end of the fiscal year). We define the discretionary component of accruals as

$$
\begin{aligned}
\text { DACCR }_{t} & =\text { ACCR }_{t}-\text { NORMALACCR }_{t}, \\
\text { NORMALACCR }_{i, t} & =\left(\frac{\sum_{k=1}^{5} \text { ACCR }_{i, t-k}}{\sum_{k=1}^{5} S_{\text {SALES }}{ }_{i, t-k}} \text { SAES }_{i, t} .\right)
\end{aligned}
$$

Therefore, we model normal accruals as a constant proportion of firm sales.

The price-to-book ratio we use to form portfolios in May of year $t$ is book common equity for the fiscal year ending in calendar year $t-1$, divided by market equity at the end of May of year $t$. We require the firm to have a valid past price-to-book ratio. Moreover, to eliminate likely data errors, we discard those firms with price-to-book ratio less than 0.01 and greater than 100 . When using Compustat as our source of accounting information, we require that the firm must be listed on Compustat for two years. This requirement alleviates most of the potential survivor bias due to Compustat backfilling data.

The Kaplan and Zingales (1997) index is: $-1.001909 *[($ Item 18 + Item 14)/Item 8] + $0.2826389 *[($ Item 6 + CRSP December Market Equity - Item 60 - Item 74)/Item 6] + $3.139193 *[($ Item 9 + Item 34)/(Item 9 + Item 34 + Item 216)] - 39.3678*[(Item 21 + Item 19)/Item $8]-1.314759 *[$ Item $1 /$ Item 8 ]. Item numbers refer to Compustat annual data items. Compustat Item 8 is lagged.

We define BE as stockholders' equity, plus balance sheet deferred taxes (Compustat Item 74) and investment tax credit (Compustat Item 208, set to zero if unavailable), plus postretirement benefit liabilities (Compustat Item 330, set to zero if unavailable), minus the book value of preferred stock. Depending on availability of preferred stock data, we use redemption (Compustat Item 56), liquidation (Compustat Item 10), or par value (Compustat Item 130), in that order, for the book value of preferred stock. We calculate stockholders' equity as follows. We prefer to use the the stockholders' equity number reported by Moody's or Compustat (Compustat Item 216). If neither is available, we measure stockholders' equity as the book value of common equity (Compustat Item 60), plus the book value of preferred stock. (We add the preferred stock at this stage, because later we subtract it in the book equity formula.) If common equity is not available, we compute stockholders' equity as the book value of assets (Compustat Item 6) minus total liabilities (Compustat Item 181), all from Compustat. To compute BE/ME, we match BE for all fiscal year-ends in calendar year $t-1(1962-2001)$ with the firm's market equity at the end of May year $t$. Following Carhart (1997), momentum is the total gross return over the previous months $t-2$ to $t-12$. Size is the market capitalization as of the end of month $t-1$.

Our profitability controls in Section 2.5 that are used to generate abnormal investment are as follows. Our first profitability control is $D / B E$, the ratio of dividends in year $t$ to year $t-1$ book equity, for those firms with positive book equity. Fama and French (2000) is our motivation for this variable. They point out that firms target dividends to the permanent component of earnings (Lintner, 1956; Miller and Modigliani, 1961; and others). We censor each firm's D/BE ratio to the range $(0,0.15)$ to limit the influence of near-zero book equity firms. The second profitability control is a nondividend-paying dummy, $D D$, that is 0 for dividend payers and 1 for those firms not paying dividends. We use this dummy to capture any nonlinearity between expected profitability and dividends. Our third and fourth profitability controls are past long-term profitability and transitory profitability, which we include to capture the substantial mean reversion in profitability documented by Fama and French. Long-term profitability is the three-year average clean-surplus profitability, $\overline{R O E} \equiv\left(B E_{t}-B E_{t-3}+D_{t-2}+D_{t-1}+D_{t}\right) /\left(3 \times B E_{t-3}\right)$ We define transitory profitability as 
$R O E-\overline{R O E}$, where $R O E$ is current profitability and is equal to $\left(B E_{t}-B E_{t-1}+D_{t}\right) /\left(B E_{t-1}\right)$. Our fifth profitability control is a loss dummy that captures the fact that firms that are losing money typically continue to do poorly in the future. Finally, to capture the phenomenon that low concentration within industry should signal intense competition and thus lower profitability, we include a Herfindahl index of equity market capitalizations for the top five firms in each two-digit SIC code industry.

\section{References}

Abel, A., and O. Blanchard. 1986. The Present Value of Profits and Cyclical Movements in Investment. Econometrica 54:249-74.

Abel, A., and J. Eberly. 2002. Investment and Q with Fixed Costs: An Empirical Analysis. Working Paper, Northwestern University.

Baker, M., R. Ruback, and J. Wurgler. forthcoming. Behavioral Corporate Finance: A Survey, in Espen Eckbo (ed.), The Handbook of Corporate Finance: Empirical Corporate Finance. New York: Elsevier/North-Holland.

Baker, M., J. Stein, and J. Wurgler. 2003. When Does the Market Matter? Stock Prices and the Investment of Equity-Dependent Firms. Quarterly Journal of Economics 118(3):969-1005.

Baker, M., and J. Wurgler. 2000. The Equity Share in New Issues and Aggregate Stock Returns. Journal of Finance 55:2219-57.

Baker, M., and J. Wurgler. 2002. Market Timing and Capital Structure. Journal of Finance 57:1-32.

Baker, M., and J. Wurgler. 2004. A Catering Theory of Dividends. Journal of Finance 59:271-88.

Barro, R. 1990. The Stock Market and Investment. The Review of Financial Studies 3:115-31.

Bergstresser, D., M. A. Desai, and J. Rauh. 2004. Earnings Manipulation and Managerial Investment Decisions: Evidence from Sponsored Pension Plans. Working Paper No. 10543, NBER.

Blanchard, O., C. Rhee, and L. Summers. 1993. The Stock Market, Profit and Investment. Quarterly Journal of Economics 108(1):115-36.

Bond, S., and J. Cummins. 2000. The Stock Market and Investment in the New Economy: Some Tangible Facts and Intangible Fictions. Brookings Papers on Economic Activity 2000(1), 61-124.

Carhart, M. 1997. On Persistence in Mutual Fund Performance. Journal of Finance 52(1):57-82.

Chan, K., K. C. Chan, N. Jegadeesh, and J. Lakonishok. 2001. Earnings Quality and Stock Returns. NBER, Working Paper No. 8308.

Chirinko, R., and H. Schaller. 2001. Business Fixed Investment and "Bubbles": The Japanese Case. American Economic Review 91:663-80.

Cochrane, J. 1991. Production-Based Asset Pricing and the Link Between Stock Returns and Economic Fluctuations. Journal of Finance 46:209-37.

Cohen, R., C. Polk, and T. Vuolteenaho. 2003. The Value Spread. Journal of Finance 58:609-41.

Cooper, M. J., O. Dimitrov, and P. R. Rau. 2001. A Rose.com by Any Other Name. Journal of Finance 56:237188.

Cooper, M. J., A. Khorana, I. Osobov, A. Patel, and P. R. Rau. 2005. Managerial Actions in Response to a Market Downturn: Valuation Effects of Name Changes in the Dot.com Decline. Journal of Corporate Finance 11:319-35

D'Avolio, E. Gildor, and A. Shleifer. 2002. Technology, Information Production, and Market Efficiency, in Economic Policy For The Information Economy, A Symposium Sponsored by The Federal Reserve Bank of Kansas City.

Daniel, K., and S. Titman. 2006. Market Reactions to Tangible and Intangible Information. Journal of Finance 61(4):1605-43. 
Dow, J., and G. Gorton. 1997. Stock Market Efficiency and Economic Efficiency: Is There a Connection? Journal of Finance 52:1087-1129.

Erickson, T., and T. M. Whited. 2000. Measurement Error and the Relationship between Investment and Q. Journal of Political Economy 108:1027-57.

Erickson, T., and T. M. Whited. 2002. Two-step GMM Estimation of the Errors-in-variables Model Using High-order Moments. Econometric Theory 18:776-99.

Fama, E. 1970. Efficient Capital Markets: A Review of Theory and Empirical Work. Journal of Finance 25:383423.

Fama, E., and K. French. 1993. Common Risk Factors in the Returns on Stocks and Bonds. Journal of Financial Economics 33:3-56.

Fama, E., and K. French. 2000. Forecasting Profitability and Earnings. Journal of Business 72:161-75.

Fama, E., and J. MacBeth. 1973. Risk, Return, and Equilibrium: Empirical Tests. Journal of Political Economy 281:607-36.

Froot, K., D. Scharfstein, and J. Stein. 1994. A Framework for Risk Management. Harvard Business Review 72:91-102.

Gaspar, J. M., M. Massa, and P. Matos. 2005. Shareholder Investment Horizons and the Market for Corporate Control. Journal of Financial Economics 76(1):135-65.

Gilchrist, S., and C. Himmelberg. 1995. Evidence on the Role of Cash Flow for Investment. Journal of Monetary Economics 36:541-72.

Gilchrist, S., C. Himmelberg, and G. Huberman. 2005. Do Stock Price Bubbles Influence Corporate Investment? Journal of Monetary Economics 52:805-27.

Hand, J. 1990. Did Firms Undertake Debt-equity Swaps for an Accounting Paper Profit or True Financial Gain? The Accounting Review 64:587-623.

Hribar, P., and D. Collins. 2002. Errors in Estimating Accruals: Implications for Empirical Research. Journal of Accounting Research 40:105-34.

Jensen, M. C. 2005. Agency Costs of Overvalued Equity. Working Paper No. 04-26, Harvard NOM; Finance Working Paper No. 39/2004, ECGI, available at http://ssrn.com/abstract=480421.

Jones, J. 1991. Earnings Management During Import Relief Investigation. Journal of Accouting Research 29:193228.

Kaplan, S., and L. Zingales. 1997. Do Financing Constraints Explain Why Investment is Correlated with Cash Flow? Quarterly Journal of Economics 112:168-216.

Lamont, O. 2000. Investment Plans and Stock Returns. Journal of Finance 55:2719-45.

Lintner, J. 1956. The Distribution of Incomes of Corporations among Dividends, Retained Earnings and Taxes. American Economic Review 46:97-113.

Maines, L., and J. Hand. 1996. Individuals' Perceptions and Misperceptions of the Time Series Properties of Quarterly Earnings. The Accounting Review 71:317-36.

Mayer, C. 1988. A New Test of Capital Structure. European Economic Review 32:1167-89.

Mayer, C., and O. Sussman. 2003. New Issues in Corporate Finance. Working Paper, Oxford University.

Miller, M., and F. Modigliani. 1961. Dividend policy, growth, and the valuation of shares. Journal of Business $34: 411-33$

Morck, R., A. Shleifer, and R. Vishny. 1990. The Stock Market and Investment: Is the Market a Sideshow?. Brookings Papers on Economic Activity 2:157-215. 
Newey, W. K., and K. D. West. 1987. A Simple, Positive Semi-Definite, Heteroskedasticity and Autocorrelation Consistent Covariance Matrix. Econometrica 55(3):703-08.

Panageas, S. 2005. The Neoclassical q Theory of Investment in Speculative Markets. Mimeo, The Wharton School, University of Pennsylvania.

Polk, C., and P. Sapienza. 2004. The Real Effects of Investor Sentiment. Working Paper No. 10563, NBER.

Polk, C., S. Thompson, and T. Vuolteenaho. 2006. Cross-sectional Forecasts of the Equity Premium. Journal of Financial Economics 81:101-41.

Rajan, R., and L. Zingales. 1995. What Do We Know about Capital Structure? Some Evidence from International Data. Journal of Finance 50:1421-60.

Rhodes-Kropf, M., D. Robinson, and S. Viswanathan. 2004. Valuation Waves and Merger Activity: The Empirical Evidence. Working Paper, Columbia Business School.

Shleifer, A., and R. Vishny. 1990. Equilibrium Short Horizons of Investors and Firms. American Economic Review Papers and Proceedings 80:148-53.

Shleifer, A., and R. Vishny. 2003. Stock Market Driven Acquisitions. Journal of Financial Economics 70:295311.

Sloan, R. 1996. Do Stock Prices Fully Reflect Information in Accruals and Cash Flows about Future Earnings? The Accounting Review 71:289-315.

Stambaugh, R. F. 1999. Predictive Regressions. Journal of Financial Economics 54:375-421.

Stein, J. 1988. Takeover Threats and Managerial Myopia. Journal of Political Economy 96:61-80.

Stein, J. 1996. Rational Capital Budgeting in an Irrational World. Journal of Business 69:429-55.

Stein, J. 2003. Agency, Information and Corporate Investment, in G. Constantinides, M. Harris, and R. Stulz (eds), The Handbook of the Economics of Finance. New York: Elsevier/North-Holland, pp. 111-65.

Teoh, S. H., I. Welch, and T. J. Wong. 1998a. Earnings Management and the Long-term Market Performance of Initial Public Offerings. Journal of Finance 53:1935-74.

Teoh, S. H., I. Welch, and T. J. Wong. 1998b. Earnings Management and the Underperformance of Seasoned Equity Offerings. Journal of Financial Economics 50:63-99.

Titman, S., K. C. J. Wei, and F. Xie. 2004. Capital Investments and Stock Returns. Journal of Financial and Quantitative Analysis 39:677-700. 